San Jose State University

SJSU ScholarWorks

Mineta Transportation Institute Publications

$12-2019$

\title{
The Potential for Using Loyalty Rewards and Incentives Programs to Encourage Transit Ridership and Regional Transportation and Land Use Integration
}

Christopher E. Ferrell

Mineta Transportation Institute

Follow this and additional works at: https://scholarworks.sjsu.edu/mti_publications

Part of the Business Analytics Commons, Marketing Commons, and the Transportation Engineering Commons

\section{Recommended Citation}

Christopher E. Ferrell. "The Potential for Using Loyalty Rewards and Incentives Programs to Encourage Transit Ridership and Regional Transportation and Land Use Integration" Mineta Transportation Institute Publications (2019). https://doi.org/10.31979/mti.2019.1797

This Report is brought to you for free and open access by SJSU ScholarWorks. It has been accepted for inclusion in Mineta Transportation Institute Publications by an authorized administrator of SJSU ScholarWorks. For more information, please contact scholarworks@sjsu.edu. 


\section{SJSU UNIVSESSTYY}

\section{$1 / 30$ ||}

The Potential for Using Loyalty Rewards and Incentives Programs to Encourage Transit Ridership and Regional Transportation and Land Use Integration

Christopher E. Ferrell, PhD

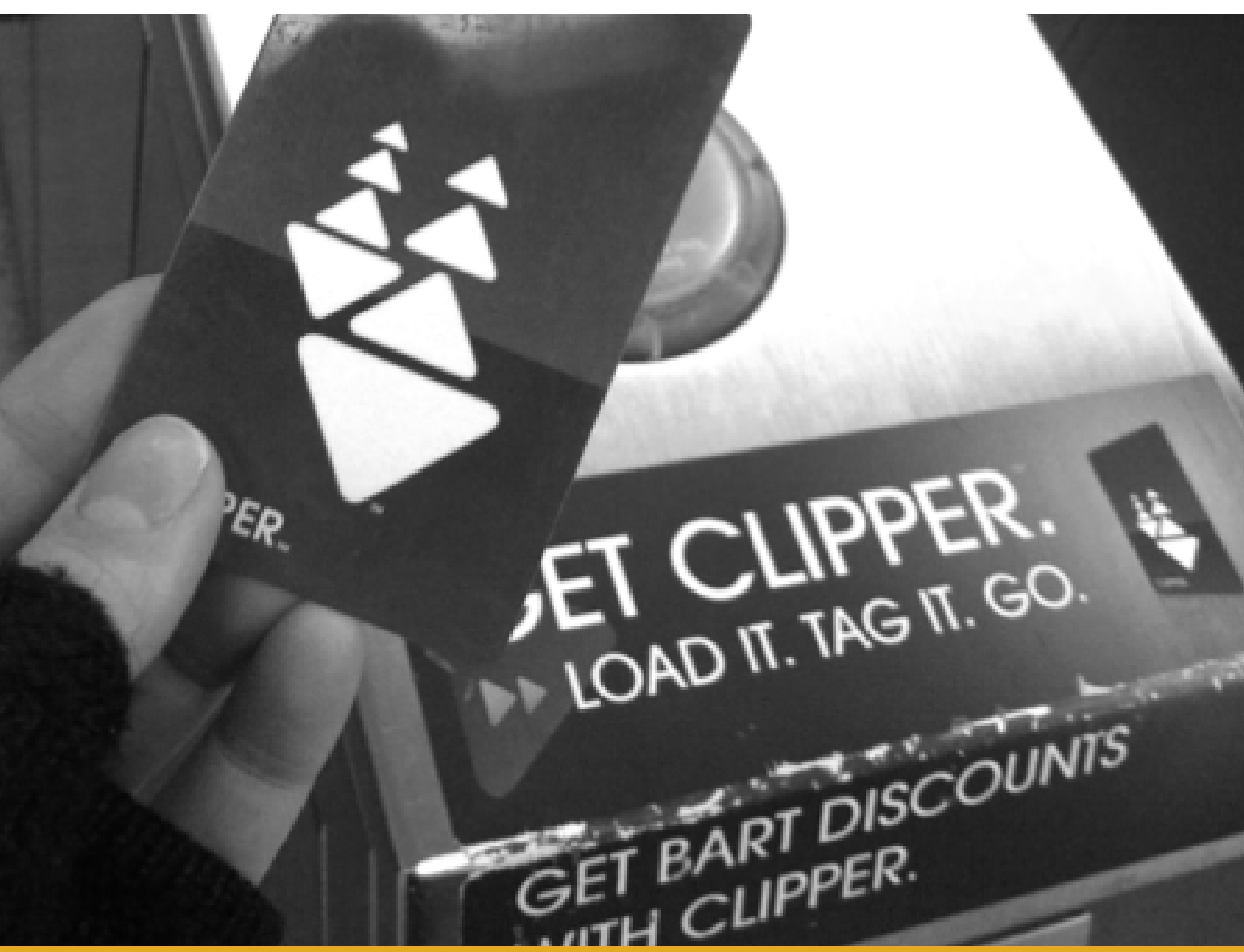




\section{MINETA TRANSPORTATION INSTITUTE \\ LEAD UNIVERSITY OF \\ Mineta Consortium for Transportation Mobility}

Founded in 1991, the Mineta Transportation Institute (MTI), an organized research and training unit in partnership with the Lucas College and Graduate School of Business at San José State University (SJSU), increases mobility for all by improving the safety, efficiency, accessibility, and convenience of our nation's transportation system. Through research, education, workforce development, and technology transfer, we help create a connected world. MTI leads the four-university Mineta Consortium for Transportation Mobility, a Tier I University Transportation Center funded by the U.S. Department of Transportation's Office of the Assistant Secretary for Research and Technology (OST-R), the California Department of Transportation (Caltrans), and by private grants and donations.

MTI's transportation policy work is centered on three primary responsibilities:

\section{Research}

MTI works to provide policy-oriented research for all levels of government and the private sector to foster the development of optimum surface transportation systems. Research areas include: bicycle and pedestrian issues; financing public and private sector transportation improvements; intermodal connectivity and integration; safety and security of transportation systems; sustainability of transportation systems; transportation / land use / environment; and transportation planning and policy development. Certified Research Associates conduct the research. Certification requires an advanced degree, generally a Ph.D., a record of academic publications, and professional references. Research projects culminate in a peer-reviewed publication, available on TransWeb, the MTI website (http://transweb.sjsu.edu).

\section{Education}

The Institute supports education programs for students seeking a career in the development and operation of surface transportation systems. MTI, through San José State University, offers an AACSBaccredited Master of Science in Transportation Management and graduate certificates in Transportation Management, Transportation Security, and High-Speed Rail Management that serve to prepare the nation's transportation managers for the 2 I st century. With the active assistance of the California Department of Transportation (Caltrans), MTI delivers its classes over a state-of-the-art videoconference network throughout the state of California and via webcasting beyond, allowing working transportation professionals to pursue an advanced degree regardless of their location. To meet the needs of employers seeking a diverse workforce, MTl's education program promotes enrollment to under-represented groups.

\section{Information and Technology Transfer}

MTI utilizes a diverse array of dissemination methods and media to ensure research results reach those responsible for managing change. These methods include publication, seminars, workshops, websites, social media, webinars, and other technology transfer mechanisms. Additionally, MTI promotes the availability of completed research to professional organizations and journals and works to integrate the research findings into the graduate education program.MTI's extensive collection of transportation- related publications is integrated into San José State University's world-class Martin Luther King, Jr. Library.

\section{Disclaimer}

The contents of this report reflect the views of the authors, who are responsible for the facts and accuracy of the information presented herein. This document is disseminated in the interest of information exchange. The report is funded, partially or entirely, by a grant from the U.S. Department of Transportation's University Transportation Centers Program. This report does not necessarily reflect the official views or policies of the U.S. government, State of California, or the Mineta Transportation Institute, who assume no liability for the contents or use thereof. This report does not constitute a standard specification, design standard, or regulation. 
REPORT 19-33

\section{THE POTENTIAL FOR USING LOYALTY REWARDS AND INCENTIVES PROGRAMS TO ENCOURAGE TRANSIT RIDERSHIP AND REGIONAL TRANSPORTATION AND LAND USE INTEGRATION}

Christopher E. Ferrell, PhD

December 2019

A publication of

Mineta Transportation Institute

Created by Congress in 1991 


\section{TECHNICAL REPORT DOCUMENTATION PAGE}

1. Report No. 19-33

4. Title and Subtitle

The Potential for Using Loyalty Rewards and Incentives Programs to Encourage Transit Ridership and Regional Transportation and Land Use Integration

7. Authors

Christopher E. Ferrell, PhD https://orcid.org/0000-0002-3285-1008

2. Government Accession No.
3. Recipient's Catalog No.

5. Report Date

December 2019

6. Performing Organization Code

8. Performing Organization Report CA-MTI-1797

\section{Work Unit No.}

Mineta Transportation Institute

College of Business

San José State University

San José, CA 95192-0219

\section{Sponsoring Agency Name and Address}

U.S. Department of Transportation

Office of the Assistant Secretary for

Research and Technology

University Transportation Centers Program

1200 New Jersey Avenue, SE

Washington, DC 20590
11. Contract or Grant No. 69A3551747127

13. Type of Report and Period Covered Final Report

14. Sponsoring Agency Code

15. Supplemental Notes

\section{Abstract}

The initial inspiration for this research project came from the idea that transit smart cards could be used as a tool for increasing transit ridership, retail sales in transit-oriented developments (TODs) and eventually, increasing retail development in TODs. This might work by expanding the scope and capabilities of transit smart cards to include "customer loyalty rewards" capabilities, thereby increasing patronage of retail businesses located in TODs. From this inspiration, a plan was developed to gather research literature on the relationships between smart cards and transit ridership, between transit ridership and retail activities, and between retail sales and retail development in TODs. In the process of this literature search, examples were identified of programs that have been implemented in North American transit agencies. For three of these cases-in Montreal, Canada; in Minneapolis/ St. Paul, Minnesota; and in the San Francisco Bay Area, California-case study profiles were developed from a combination of source publication materials, traditional and electronic media, and telephone interviews with program representatives.

\section{Key Words}

Public Transit; Transit Ridership;

Transit-Oriented Development; Marketing; Smart Cards

\section{Distribution Statement}

No restrictions. This document is available to the public through The National Technical Information Service, Springfield, VA 22161
19. Security Classif. (of this report) Unclassified
20. Security Classif. (of this page) Unclassified
21. No. of Pages

73
22. Price 


\title{
Copyright () 2018 \\ by Mineta Transportation Institute \\ All rights reserved
}

DOI: 10.31979/mti.2019.1797

\author{
Mineta Transportation Institute \\ College of Business \\ San José State University \\ San José, CA 95192-0219 \\ Tel: (408) 924-7560 \\ Fax: (408) 924-7565 \\ Email: mineta-institute@sjsu.edu
}

transweb.sjsu.edu 


\section{ACKNOWLEDGMENTS}

The authors thank Editing Press, for editorial services, as well as MTI staff, including Executive Director Karen Philbrick, PhD; Deputy Executive Director Hilary Nixon, PhD; Graphic Designer Alverina Eka Weinardy; and Executive Administrative Assistant Jill Carter. 


\section{TABLE OF CONTENTS}

Executive Summary 3

$\begin{array}{ll}\text { I. Introduction } & 4\end{array}$

II. Literature Review $\quad 5$

Setting the Stage: Linking Smart Cards, Ridership, and Transit-Oriented Development-Based Retail 5

The Effectiveness of Transit and Retail Rewards Programs 8

III. Transit Rewards Programs in Practice $\quad 19$

Montreal, Quebec: Société De Transport De Montréal's STM Merci! Program 19

Minneapolis/St. Paul, Minnesota: Metro Transit's Ride to Rewards Program 26

San Francisco Bay Area: BART Perks Program 30

Other Notable Transit Ridership Rewards Programs 35

IV. Conclusions and Implications for Future Research, Policies and Practice 38 $\begin{array}{ll}\text { Policy/Practice Recommendations } & 40\end{array}$

Abbreviations and Acronyms $\quad 41$

$\begin{array}{ll}\text { Endnotes } & 42\end{array}$

$\begin{array}{lr}\text { Bibliography } & 64\end{array}$

$\begin{array}{ll}\text { About the Author } & 72\end{array}$

$\begin{array}{ll}\text { Peer Review } & 73\end{array}$ 


\section{LIST OF FIGURES}

1. Screenshot of STM Merci! App 22

2. Metro Transit's Ride to Rewards Program Online Points Activity Screen 27

3. Metro Transit's Ride to Rewards Program Process 28

4. Metro Transit's Ride to Rewards Program Benefits 29 


\section{EXECUTIVE SUMMARY}

The initial inspiration for this research project came from the idea that transit smart cards could be used as a tool for increasing transit ridership, retail sales in transit-oriented developments (TODs) and eventually, increasing retail development in TODs. This might work by expanding the scope and capabilities of transit smart cards to include "customer loyalty rewards" capabilities, thereby increasing patronage of retail businesses located in TODs. Instead of providing separate loyalty rewards for each store or chain of stores, such cards would provide loyalty rewards -in several possible forms, including free transit ride credits, cash rewards, retail purchase discounts, sweepstakes rewards-to all transit riders who patronize TOD retail businesses. Additional rewards could be given to transit riders who live, work, and shop in TODs, and even to riders who take transit for specific shopping trips in TODs. In this way, smart cards and transit loyalty programs could become not only useful tools for increasing transit ridership, but also tools for targeted economic development of individual TODs, a means to increase economic opportunities and equity for low-income residents and shoppers in inner-city commercial zones, and in its most fully-realized application, a tool for regional planners to concentrate retail, services and housing in priority development areas, consistent with smart-growth planning principles.

From this initial inspiration, a plan was developed to gather research literature on the relationships between smart cards and transit ridership, between transit ridership and retail activities, and between retail sales and retail development in TODs. In the process of this literature search, examples were identified of programs that have been implemented in North American transit agencies. For three of these cases-in Montreal, Canada; in Minneapolis/St. Paul, Minnesota; and in the San Francisco Bay Area, California-case study profiles were developed from a combination of source publication materials, traditional and electronic media, and telephone interviews with program representatives.

This literature review and case study research resulted in the identification of a number of practical lessons, and promising directions for future research:

1. There is a lack of research linking transit smart cards, transit ridership, and shopping behavior in TODs.

2. It is important to retain existing transit riders (reducing ridership "churn"), potentially through the use of loyalty rewards programs and incentives programs to keep these riders or win back those who have given it up.

3. There is both need and potential for rebranding transit's public image.

4. There are risks of overreach when implementing a transit loyalty rewards and incentives program.

5. There is high potential of incentives and loyalty rewards programs in building transit ridership, TOD, and beyond. 


\section{INTRODUCTION}

This report provides a compilation and analysis of the literature, and of three case studies, on the potential for rewards- and incentives-based programs in the North American transit industry. The initial inspiration for this research came from the idea that transit smart cards could be used as a tool for increasing transit ridership, increasing retail sales in transit-oriented developments (TODs) and eventually, increasing opportunities for retail development in TODs. This might work by expanding the scope and capabilities of transit smart cards to include "customer loyalty rewards" capabilities, thereby increasing patronage of retail businesses located in TODs. Instead of providing separate loyalty rewards for each store, or chain of stores, such cards would provide loyalty rewards-in several possible forms, including free transit ride credits, cash rewards, retail purchase discounts, sweepstakes rewards - to all transit riders who patronize TOD retail businesses. Additional rewards could also be given to transit riders who live, work, and shop in TODs, and even to riders who take transit for specific shopping trips in TODs. In this way, smart cards and transit loyalty programs could become not only useful tools for increasing transit ridership, but also tools for targeted economic development of individual TODs, a means to increase economic opportunities and equity for low-income residents and shoppers in inner-city commercial zones, and in their most fully-realized expression, as tools for regional planners to concentrate retail, services and housing in priority development areas consistent with smart-growth planning principles.

From this initial inspiration, a plan was developed to gather research literature on the relationships between smart cards and transit ridership, between transit ridership and retail activities, and between retail sales and retail development in TODs. In the process of this literature search, examples were identified of programs that have been implemented in three North American transit agencies. Case study profiles were developed from a combination of source publication materials, traditional and electronic media, and telephone interviews with program representatives.

Three topics discussed in the literature are central to this research (sometimes referred to here as "the benefits"): 1) the best economic development practices and outcomes for retail; 2) the ridership effects of transit smart card programs; and 3) the effects of incentives programs, membership and other rewards programs on retail and travel behavior. An overview of the literature in these topic areas follows, highlighting subjects that are either relatively new or not as well-known in the transportation planning community.

This overview and analysis of the literature is followed by summaries of three case studies of transit rewards and/or loyalty programs in North America: Montreal, Canada; Minneapolis/ St. Paul, Minnesota; and the San Francisco Bay Area, California. 


\section{LITERATURE REVIEW}

Total U.S. transit ridership has largely been in decline since the end of World War Two as households, retail, and other employment have followed the development of highways to the suburbs..$^{1,2}$ Transit-oriented development (TOD) is an approach to urban planning that seeks to draw residents and employers back to more urban and walkable environments near high-capacity transit stations, so that transit modes can recapture a larger share of the metropolitan transportation market. In doing so, TODs are seen as tools for helping create additional benefits to society including reduced vehicle-miles of travel, reduced greenhouse gas emissions and other air pollutants, reinvigorated and more equitable inner city economies, and enhanced quality of life..$^{3,4,5,6,7}$ However, the successful development of TODs has proven challenging, causing planners, policy-makers and developers to look for more powerful and targeted policies and incentives to enhance TODs' prospects.

This study proposes an approach to incentivizing retail sales, transit ridership, and retail development in TODs through the coordination of transit smart cards, rider loyalty rewards programs, and retail purchasing discounts targeted to TOD station areas. The present section reviews literature relevant to various components of this proposed approach. It begins with a review of research into the influences of TODs on retail sales and development. This is followed by a summary of research on the success of, and the challenges facing, retail outlets located in TODs. The review then turns to an overview of the research into the effects of transit smart cards on ridership, and the effects of retail and transit loyalty rewards programs on consumer and travel behavior.

\section{SETTING THE STAGE: LINKING SMART CARDS, RIDERSHIP, AND TRANSIT- ORIENTED DEVELOPMENT-BASED RETAIL}

This section brings together research literature on the effectiveness of TOD at attracting retail. This literature suggests a mixed picture at best, with very few sources focusing on this important aspect of TOD planning at all, and with only some of those showing successful retail-in-TODs or highlighting the best practices for helping to bring it about. Faced with these challenges, the remainder of this section then investigates ways in which smart cards might be used to incentivize transit ridership, retail sales, and retail development within TODs.

\section{Retail Economic Development Challenges and Practices for Transit-Oriented Developments}

The literature search performed for this project found very few sources on the challenges to and practices for retail development in TODs. Blais argues that in many ways suburban sprawl development is driven by a combination of "perverse incentives" that can make, among other things, retail development cheaper in greenfield (as opposed to "brownfield" or otherwise already-developed) areas; these incentives include average-cost pricing services (where service providers charge for the lower, average costs of extending their infrastructure to greenfield areas instead of the often, higher marginal costs) for development and municipal, water and sewer connections, and even mundane things like cable TV service, all of which contribute to making suburban development cheap. ${ }^{8}$ While 
these cost advantages may seem small, they can have large consequences favoring, among other types of development, suburban, auto-oriented retail (e.g., so-called "big box stores").

Guy provides additional support for Blais' argument, focusing on the effects of these incentives on the viability of retail in walkable and transit-oriented neighborhoods. Guy developed an economic model of competition between "walkable" shops such as would be found in a TOD, and auto-oriented retail outlets, in order to help explain the challenges that TODs face. He found that while auto-oriented shops tend to have small cost advantages over their smaller, transit-oriented competitors, these advantages can translate into large price advantages for the auto-oriented retail establishments. ${ }^{9}$ Lower prices in suburban stores leads to a competitive advantage in the regional marketplace as high levels of auto ownership in U.S. cities tend to offer additional incentives to shoppers to make long car trips to find lower prices at the suburban fringe. Guy also points out the equity consequences of these perverse incentives, suggesting that high prices in walkable, urban shops are in effect a regressive transfer of wealth from poorer to richer consumers, since low-income consumers are less likely to own cars. ${ }^{10}$

Based on his research, Guy recommends "[i]nternalizing environmental and social costs of urban automobile use could [help] reduce prices and increase capacity utilization in walkable shops in more densely populated local areas." ${ }^{11}$ In part, this literature review and analysis has a similar goal-to address the market imbalances favoring suburban retail development-but instead of attempting internalize the external costs of auto use and suburban sprawl, this project investigates the potential for the development of a system of transit-oriented ridership, retail rewards, and development incentives that may have a similar effect of reducing the costs of living in urban, TOD neighborhoods.

Schuetz, focusing directly on TOD and retail, studied the changes in retail employment after the opening of new rail stations in California's four largest metropolitan areas. Most of these stations were in areas that already had high employment densities, but were outside of city centers. These new stations' openings were not statistically significantly associated with changes in retail employment for Los Angeles, San Francisco or San Diego regions, but were negatively (statistically significantly) associated with retail employment levels after opening in the Sacramento region. ${ }^{12}$ These findings suggest that TODs may not be conducive to retail development (at least in station areas outside of city centers in California).

Grant and Perrott suggest that these shortcomings of TOD retail development may be due in part to the theories, attitudes, and approach of urban planners. Comparing the experiences of planners working to bring retail to mixed-use, compact developments in three Canadian cities, they found that planners tend to approach these efforts using "evolutionary" theories of urban development, whereby they try to design "walkable" and "sociable" communities, where people will want to live, with the expectation that retail development will then naturally occur. This theory-based approach is in sharp contrast to the views, motivations, and approach of developers, who instead look to consumer's already-existing behaviors to determine where retail will be successful-in other words, big-box outlets are manifestly successful while TOD-based retail establishments, motivated 
and justified using theoretical constructs, are more problematic. ${ }^{13}$

Nevertheless, several studies offer hope for TOD retail business success. Credit studied the impacts of light rail on new business formation in station areas in Phoenix, Arizona, and found that adjacency to transit was associated with an $88 \%$ increase in new business formation in the knowledge sector, a $40 \%$ increase in the service sector, and a $28 \%$ increase in retail. ${ }^{14}$

Lee studied the factors associated with retail-space vacancies in eight mixed-use developments built between 2007 and 2017. He argued that vacancies were primarily the result of an "imbalance" between the incentives of three important stakeholders for retail in these developments: the City, the developer and the business community. When these three stakeholders harmonize their incentives through cooperation, the retail portions of mixed-use properties are more likely to be successful. ${ }^{15}$

The notion that collaboration between stakeholders will improve retail development prospects is echoed in the findings of Rao and Summers. Their comparison of retail adaptations to changing market conditions (e.g., the rise of suburban big box stores) in Portland, Oregon and in Edmonton, Alberta, suggests that retail businesses in Portland fared better than those in Edmonton due in part to Portland's more flexible and cooperative planning systems. In Portland, planners, policy-makers, the business community and other stakeholders play cooperative roles in a "polycentric", diverse planning process focused on consensus-building, whereas Edmonton's process was more rigid and "... rooted in a specific rational plan for the city." ${ }^{16}$ This study points to the potential benefits of cooperation and collaboration between public- and private-sector stakeholders. Such collaboration would also likely be required to implement and operate a combined transit ridership and retail rewards program.

\section{The Ridership Effects of Transit Pass and Smart Card Programs}

The development and widespread introduction of transit smart card systems in recent decades provides an opportunity to implement more targeted and effective transit rewards and incentives programs than were possible in the past. By building a loyalty rewards or other incentive program on top of an existing smart card system, the benefits of both could be leveraged and enhanced.

A few recent studies have documented evidence that smart card systems can measurably increase transit ridership and the propensity of individuals to shift modes to transit. Ellison et al. found that the introduction of Sydney's smart card program was associated with reductions in car use of about 10 minutes per day per person and commensurate increases in transit usage and walking. ${ }^{17}$

Sutter et al. found that the expansion of the New York Metropolitan Transportation Authority's (MTA's) stored value card (MetroCard) into Westchester County's Bee-Line transit system was associated with a substantial increase in ridership on those Bee-Line routes with direct connections to MTA routes. ${ }^{18}$ 
The introduction of London's Oyster smart card system in 2003 was associated with a $56 \%$ increase in bus ridership and a $21 \%$ increase in the London Underground's rail ridership over the following ten years. However, this must be placed in the context of other factors, including significant changes to transit operations and the implementation of a congestion charge on auto travel in central London during this same period. Therefore, isolating the effects of the Oyster card on ridership is difficult. ${ }^{19}$

In preparation for implementing a smart card system in the Philadelphia region, (the region's metropolitan planning organization, the Delaware Valley Regional Planning Commission (DVRPC) conducted a study of the potential effects on ridership and revenues from implementing a parallel fare reduction incentives program-similar in some respects to the ideas put forward in this research project to use fare incentives as a reward for transit ridership, retail purchases in transit-oriented developments (TODs), and other pro-TOD behaviors. This study found that in the short term, while fare discounts would increase ridership, the lost revenues from these reduced fares would also create a net reduction in transit revenues overall; however, it also found that these revenues would likely be compensated for by the enhanced efficiencies of the new smart card system. ${ }^{20}$

\section{THE EFFECTIVENESS OF TRANSIT AND RETAIL REWARDS PROGRAMS}

In 2016, Americans were enrolled in a total of 3.8 billion customer loyalty (retail rewards) programs. However, of those memberships, American loyalty program members actively participated in only $46 \%$ of them. ${ }^{21}$ In other words, more than half of the memberships for which Americans signed up for are not of sufficient value for them to use regularly. Interpretation of these statistics suggest that there are a variety of membership and retail loyalty programs that have different levels of effectiveness.

Wax presents a literature review of research that into the efficacy of rewards systems at motivating desired behavior. He concludes that since people are often better motivated by intrinsic rewards (e.g., a sense of purpose or accomplishment) than by extrinsic rewards (e.g., money), rewards programs should be designed to provide participants with a purpose larger than themselves; that the programs' effectiveness should be measurable with respect to those intrinsic rewards; and that such programs should make personal learning ${ }^{22}$ a primary reward for the participant. ${ }^{23}$ In other words, Wax argues, rather than effectively bribing customers into patronizing their business with extrinsic rewards, businesses should focus on creating meaningful experiences and evoking meaningful associations for customers.

\section{The Benefits of Transit Rewards Programs}

Recent development and growth of "new mobility" options in transportation-including Transportation Network Companies (TNCs) like Uber and Lyft, and bicycle- and scooterrental companies like Lime and Bird-have played a role in reducing transit ridership in the United States. ${ }^{24,25,26}$ According to a 2013 survey of millennials' transit use by the American Public Transportation Association (APTA), there has been a trend towards reduced transit usage over time, in part due to a perception that it is no longer as cost-effective, efficient, or accessible to services as other transportation modes, particularly driving. ${ }^{27,}{ }^{28}$ With total 
transit ridership flat or dropping around the country, ${ }^{29}$ particularly for off-peak, non-commute trips, transit agencies are looking for ways to win new riders and hold on to the ones they have by reducing customer "churn," defined as the number or riders lost, divided by the total number of riders. ${ }^{30}$ Ridership loyalty and incentives programs offer a possible set of tools for stemming and even reversing these trends.

Customer loyalty and other rewards programs have a long history in the retail and airline industries. Dating back to at least the $18^{\text {th }}$ century, loyalty programs are a staple of American retail marketing. ${ }^{31}$ More recently, U.S. airlines started their first loyalty and mileage rewards programs in the late 1970s and early 1980s. ${ }^{32}$ However, there have been relatively few examples of such programs in the arena of public transit, at least in the United States. Nevertheless, the potential for loyalty rewards programs in the transit industry has been gaining new attention in recent years, with several high-profile and technically sophisticated examples_-including Montreal's STM Merci!, the San Francisco Bay Area's BART Perks, and Minneapolis/St. Paul's Ride to Rewards programs-from which we can begin to draw conclusions.

Loyalty rewards programs are particularly well-regarded for their effectiveness at reducing customer churn. A store's current patrons are more likely to be loyal, and therefore, it is likely easier (and cheaper) to retain existing customers using a loyalty rewards program than it is to attract new customers. Furthermore, loyal customers are also more likely to recommend or even evangelize a company's products and services to their friends, bringing in new customers as well. With declining ridership, churn prevention is likely to become an important element of a successful transit agency in the future. ${ }^{33}$

Rewarding and recognizing the loyalty of existing riders can help address part of the problem of ridership churn. ${ }^{34}$ According to CTDOT Transit Administrator Michael Sanders, "[t]he [transit] industry typically loses 20 to 25 percent of its customers each year." 35 Burnett also suggests that the transit rider churn rate is on the rise. ${ }^{36}$ However, the present report's review of the academic literature found only two sources addressing churn in transit ridership markets, and neither directly addressed rates of change in transit ridership churn. ${ }^{37,}{ }^{38}$ Nevertheless, churn is important since it is generally less difficult and expensive to hold on to existing customers than it is to attract new ones. ${ }^{39}$ This is particularly true for capital-intensive service industries like transit, where attracting new customers often takes the form of service expansions that can require expensive infrastructure investments. Furthermore, the size of transit-dependent (or so-called "captive") rider markets is shrinking in the U.S., as more households gain access to private vehicles. Hence, the transit industry must increasingly seek ridership growth from the discretionary travel market, where efforts at ridership retention must take on a more important role. ${ }^{40}$

Therefore, if we assume that ridership retention is important for transit agencies, just as it is in other service and retail industries, then it would be in their interest to learn more about their customers, what they like and dislike about their transit system, and how those opinions affects their loyalty to that system. Supporting this notion, recent research has shown that having a positive image of public transit helps increase customer loyalty and retain existing ridership. ${ }^{41,42,43}$ 
In recent years, the North American transit industry has begun to experiment with methods for increasing customer loyalty. ${ }^{44,45,46,47}$ These experiments increasingly suggest that loyalty programs can be a cost-effective way to retain and increase transit ridership. ${ }^{48}$ However, the transit industry is relatively new to this approach, and much can be learned by looking to the loyalty program experiences of other service and retail industry actors over the years.

Understanding the customer is a primary imperative of any loyalty program. Loyalty programs that understand their customers and how to motivate them will be the most effective at building brand loyalty, retaining customers, and attracting new ones. ${ }^{49}$ Understanding customers requires data collection and analysis to allow a transit service provider to predict when and why a customer might stop riding. From these analyses, transit agencies can develop incentives that can build loyalty and keep them riding. ${ }^{50,51}$

\section{The Effects of Membership and Incentives on Retail and Travel Behavior}

According to Autry, Americans hold a total of 3.8 billion loyalty rewards memberships. Loyalty memberships have been growing at a rapid pace-as high as $26 \%$ between 2014 and 2015-until recently, when it slowed to 15\% per year between 2015 and 2016. Nevertheless, generational trends seem to be in favor of loyalty programs, with $79 \%$ of Millennials and Generation X-ers surveyed say their choice of where to shop will be influenced by whether the store has a "strong loyalty/discount program" while only $74 \%$ of Baby Boomers and $66 \%$ of seniors feel the same. ${ }^{52,53}$

Consumer choice and purchases are driven by loyalty rewards programs, with $79 \%$ of consumers looking for deals in loyalty and reward programs before shopping (doing research online, reviewing circulars and print ads, and talking to people in their personal network). Loyalty is difficult to achieve and maintain, as $54 \%$ of loyalty memberships are inactive and $28 \%$ of loyalty members abandon their programs without redeeming any points. ${ }^{54}$

There are many ways to structure a loyalty rewards program to maximize its potential, but the evidence suggests that the most-valued loyalty programs provide some form of monetary benefits. When looking internationally, more than half of the world's loyalty program participants say product discounts are among the most valued benefits. ${ }^{55}$ North and Latin Americans show a slight preference for rebates and cash back rewards rather than discounts, however, suggesting that in some cases a loyalty program should consider a nuanced, menu-of-options approach to program benefits as opposed to a generic, onesize-fits-all system. ${ }^{56}$ Rewards program designers should nevertheless be wary of providing so many options that participants are confused and frustrated.

\section{Incentives}

As seen for other aspects of this topic, this research project found only a few studies on the effects of transit incentive programs on travel behavior. One example is a 1997 study by McLaughlin and Boyle, who surveyed best practices for using incentives programs to encourage ridership among transit-dependent populations. ${ }^{57}$ 
Giving incentives for desired behaviors is a long-standing method for getting firsttime customers to try a service and increase sales. The effectiveness of simple and understandable incentives programs is illustrated in the ride-sourcing industry by Uber and Lyft. These companies regularly reward their riders by giving ride credits of $\$ 5$ to $\$ 25$ and cash rewards for downloading, using and sharing their services ${ }^{58}$ Both companies also give cash bonuses for new driver referrals..$^{59,60}$ Smartphone parking apps like BMW's ParkNow, and ParkingPanda, encourage users by offering discounted parking, while another app, GasBuddy, encourages drivers to use their app to find inexpensive gas stations by entering users to win $\$ 100$ of free gas. ${ }^{61}$

Graham notes that "[w]hile consumers prefer saving money overall, they also show a strong preference for VIP-style incentives," where customers receive perks like exclusive, preferential shopping hours or VIP lounge access. Graham also points out that new startups are currently experimenting with other incentive methods, ones that try to drive customer interactions with web sites and checking-in at stores on their mobile apps. This trend towards digitally-based rewards programs, as opposed to traditional card-based membership programs, is also supported by Graham's survey which found that while a plurality of respondents preferred card-based programs $(36.8 \%)$, the preference for digital-based programs was not far behind (33.3\%) (and 29.9\% responding they were "not sure"). These digital innovations are increasingly popular with businesses as well since they are helping to drive down the administrative costs of loyalty rewards programs while also potentially increasing the profits, providing opportunities for small- and medium-sized businesses who were previously unable to afford these programs. ${ }^{62}$

Graham suggests that people will likely grow more comfortable with digitally-based programs over time, and that in the meantime, loyalty program designers should consider hybrid systems that use both digital and card-based elements. ${ }^{63}$ Increasingly, online retailers are finding that digital enhancements to their loyalty programs pay dividends in customer memberships and involvement. Nielsen's 2016 survey of loyalty program members found that $66 \%$ of respondents would shop online more often if they were given loyalty membership programs and benefits similar to those given in brick-and-mortar stores. Retailers, both traditional and online, are increasingly seeing the benefits of providing digital elements to their loyalty programs, since among other things, these allow for enhanced customer data collection opportunities and a plethora of advanced data analytics capabilities that enable a new and dynamic understanding of their customers' shifting needs, desires, and preferences over time. These findings are helping to spur the incorporation of mobile and other digitally-based experiences into loyalty programs. ${ }^{64}$

Shaheen et al. identify four categories of point system typically used in transportationrelated smartphone apps: ${ }^{65}$

- Experience Points: Awards points for regularly using the app. Waze and Moovit are examples of apps where experience points are given to users to encourage desirable use habits. ${ }^{66}$

- Redeemable Points: Points both awarded and redeemed within an app, and encourage the user to do the maximum number of activities there. In addition 
to airline frequent flyer programs, and Amtrak's frequent rider program, in-app redeemable point systems are being used in transportation apps intended to reduce congestion and encourage alternatives to the automobile such as NuRide, ${ }^{67}$ Stanford University's CAPRI, ${ }^{68}$ and Metropia. ${ }^{69,70}$

- Skill Points: Points awarded for the completion of a desired in-app task. Waze and GasBuddy, for example, both award points to users based on adding information to their systems about such as road conditions (in the case of Waze) and gas prices (in the case of GasBuddy). ${ }^{71}$

- Reputation Points: Awards points using a rating system for services rendered. Examples include Lyft and Uber where riders and drivers rate each other with the expectation that good behaviors (e.g., safe driving) will be encouraged when each participant knows their reputation is at stake. ${ }^{72}$

\section{Social Rewards}

Graham asked survey respondents if they would be more likely to participate in a loyalty program if they received social rewards, such as FourSquare-style digital badges. ${ }^{73}$ According to Walker, FourSquare's badges use "gamelike elements to quantify, reinforce, and even influence the actions of its users." For example, by checking in at your favorite restaurant more than anyone else over a given time period, FourSquare anoints the participant as the "mayor" of that establishment. Gather enough mayoralties from other locations, and the participant will receive a "Super Mayor" badge on their profile screen, which presumably offers bragging rights in addition to other incentives and rewards that these establishments may offer. ${ }^{74}$

Nevertheless, Graham's survey results suggest that social loyalty program rewards are not an effective reward for loyalty program participation, with only $14.1 \%$ saying they would be more likely to participate and only $2.3 \%$ saying they would be much more likely to participate if social rewards were available. ${ }^{75}$

\section{VIP Rewards}

In contrast with social rewards, Graham also found that people were highly motivated by VIP "perks" that provide them with a feeling that their loyalty program participation provided them with access to rewards they otherwise would not get. In contrast to the effects of social rewards-where only 16.4 percent of respondents said they were more likely or much more likely to participate if they received these rewards- $56.8 \%$ of respondents said that they would be more or much more likely to participate if they received exclusivitybased perks. Graham concludes that the best structure for a loyalty program is a "tiered" or level-based system, similar to airline rewards programs that provide exclusive or higher rewards for increased patronage. ${ }^{76}$

Flexibility in rewards programs may also be an important element for customers. In the 2016 Nielsen survey, $80 \%$ of respondents said that they found a rewards program more appealing when it offered rewards regardless of where they made their purchase, whether 
in-store, through a website, or on their mobile devices. Additionally, $79 \%$ of respondents said their program would be more appealing if it allowed the customer to choose among several kinds of rewards. ${ }^{77}$

Therefore, loyalty rewards programs are probably most effective when they are flexible and customizable to the needs and tastes of specific consumers. This can include both flexibility of loyalty program engagement interface (e.g. app, email, or in-store interaction), and flexibility to match customers' preferences within the loyalty program itself. Different customers have different optimal experiences, and so no one-size-fits-all rewards program is optimal. ${ }^{78}$

\section{"Gamification" in Transportation Applications}

Gamification is a relatively new field of study and applications, wherein the principles of game mechanics and design are applied to non-game environments to enhance user satisfaction and increase desired behaviors. The principles of gamification hold great potential for designing effective successful transit rider rewards programs. Augustus and Kiernan researched the potential for gamification applications for Los Angeles Metro to enhance rider enjoyment while taking transit. ${ }^{79}$

Bond Brand Loyalty's Loyalty Survey Report for 2017 found that loyalty program members who agree that a program is enjoyable are 10 times more likely than otherwise to be satisfied.$^{80}$ Various attempts have been made to make programs more enjoyable. In one attempt, Kuramoto et al. designed a game application for subway riders who are forced to stand while on the train, in an attempt to encourage them to continue standing and riding even when seats are scarce. This 12-week experiment found that the game encouraged riders to stand for the first 8 weeks, but the effect declined thereafter. ${ }^{81}$ In another, Kazhamiak et al. developed and evaluated a gamification framework for use within the STREETLIFE EU smart city project, a platform offering a means for game developers to provide games based on existing smart city applications, encouraging sustainable transportation behaviors. As a test of this platform, STREETLIFE EU introduced a game called "Green Game" for 36 users of their recently implemented a mobile trip routing app, "ViaggiaRovereto" in Roverto, Italy. The game provided three types of points to users: "Green Points," which awarded points to users who used sustainable transportation modes; "Health Points," which awarded points for the amount of walking and bicycling; and "Park\&Ride Points," where points were given for the use of park-and-ride facilities. Similar to FourSquare (described above), Green Game also awarded badges based on the points accumulated by each user over a set period of time. Evaluation of the Green Game app use and travel behaviors of the 36 pilot test participants found that gamification significantly incentivized them to: (1) use the underlying trip planning app (ViaggiaRovereto) more; (2) use the route alternatives provided by ViaggiaRovereto more; and (3) travel less by private car. ${ }^{82}$

\section{Ingredients for Loyalty Program Success}

Customer loyalty programs generally have two types of benefits that are used in tandem to promote customer retention: "hard" benefits such as discounts, perks and other tangible rewards; and "soft" benefits that help create an emotional connection between a customer 
and the service. Soft benefits might include opportunities to easily share experiences on their transit ride, or to share the loyalty program itself, on social media. ${ }^{83}$

Burnett identifies eight major benefits of loyalty programs for retail and service providers, and in the process, also provides recommendations for optimizing such programs (modified here to address transit agencies specifically): 84

1. Keeping Current Riders. A low rider retention rate in one year is a problem, but if it continues over time, the results can be disastrous. Over a five-year period, a transit agency with a $70 \%$ rider retention rate will have lost two to three times as many riders as an agency with a $90 \%$ retention rate. Not only does a loyalty program provide a practical reason for continuing to ride (the accumulation of points toward a reward, or higher levels of service), but it also provides rider information to the transit agency that allows them to understand and predict their needs and behaviors, thereby helping with rider retention..$^{85}$

2. Attracting New Riders. While new rider acquisition is not usually the main goal of a loyalty program, there are tangible benefits to be had here as well. If the benefits to new riders can be made attractive enough, a transit agency can raise its profile and image with both riders and non-riders, leading to new ridership. ${ }^{86,87}$

3. Rewarding "Profitable" and Discouraging "Unprofitable" Behaviors. This benefit, originally titled "Say Goodbye to Unprofitable Customers" by Burnett (wherein unprofitable customers are discouraged from future patronage), ${ }^{88}$ is potentially problematic for the transit industry as it is generally a public sector service that holds equity as a goal of equal value to the goal of financial return. This so-called "triple bottom-line" approach, whereby social, environmental and financial goals are held to be more or less in equal standing, ${ }^{89}$ has increasingly been adopted by public agencies, including transit providers. Therefore, a transit agency would be seen as failing in its goal of equity if it "said goodbye" to socially and economically disadvantaged riders, simply due to their being financially unprofitable. As such, Burnett's original recommendation has been modified to focus on reducing unprofitable behaviors among customers, rather than abandoning unprofitable customers themselves. Therefore, it is possible that a loyalty program may be helpful in discouraging unprofitable behaviors, turning "unprofitable" riders into "profitable" riders. For example, fare evasion could be discouraged by rewarding riders for paying their fares with points accumulated towards future rewards.

4. Familiarity (of Riders and of Transit Agencies). It is typically easier to attract former customers (assuming their experiences weren't extremely negative) than it is to attract new ones. According to Burnett, "the success rate in approaching 'lost' customers can be three to four times as high as it is when prospecting for new customers." ${ }^{90}$ The reasons for this are twofold. Firstly, former riders already have experiences with the transit system, giving that agency a greater chance of finding a positive association that might draw them back. Secondly, the transit agency may have information on those lost riders as well that can help with their efforts to bring them back; for example, the transit agency may have information about their past 
travel behavior history, and where and how to reach them. ${ }^{91}$

5. Building Rider Relationships. Building a relationship between transit agency and rider is an ongoing process that demands attention and flexibility on the part of the transit agency. Riders' tastes, needs, values and lifestyles change over time, requiring the transit agency to be aware of these changes, through data collection and analysis, and then to adjust their services to meet them. ${ }^{92}$

6. Creating Advocates. Loyalty programs can help create customer-advocates who use word-of-mouth to show support for a service provider. Word-of-mouth advocates can be powerful image-builders ${ }^{93}$ for a transit agency, evangelizing their transit-riding and loyalty program rewards to their friends and associates. Advocates who give this type of personal recommendation to their friends can be far more convincing than any amount of promotional material. ${ }^{94}$

7. Remaining Competitive. As noted earlier, transit is increasingly competing directly with "New Mobility" providers (e.g. Uber, Lyft). A loyalty program can help transit agencies remain competitive by identifying customers who are defecting, enticing them back with new rewards, continued rewards and other signs of gratitude for their continued loyalty. ${ }^{95}$

8. Targeted Transit Services. Beyond the direct benefits a loyalty rewards program can offer, the relationship between a transit agency and its regular riders can also be leveraged to build a greater understanding of what type and amount of transit services will best serve them. Burnett recommends to retailers that they "[a]djust [their] stock to suit the more profitable customers that [they] already have," after which the "[l]ess profitable customer groups tend to self-select themselves out since the shelves are now less appealing to them." ${ }^{\prime 66}$ While equity consequences should also considered when adjusting transit services in such ways, altering service frequencies, rolling stock, routes, and other operational parameters to provide a better match to loyal and responsive customers can provide a powerful tool for agencies to retain existing riders.

The 2016 Nielsen survey identified the following strategies for designing and operating a loyalty program for success ${ }^{97}$ :

1. Monitoring and measuring performance. Loyalty program data can be used to drive better business decisions. Granular, detailed loyalty customer data can be combined with market surveys and other media in order to create an in-depth picture of a business' customers and create better services and products. ${ }^{98}$

2. Using market segmentation tools. Loyalty programs should be personalized for your customers. Customers can be identified by market segment through the use of rich, personalized data gathered through the loyalty program. ${ }^{99}$

3. Personalizing the customer experience. Loyalty programs should be designed to meet the needs of customers, providing a rich and flexible user experience tailored 
to the shopping habits of each individual to drive customer affinity. ${ }^{100}$

4. Providing offers that customers value. Loyalty program data and predictive analytics can be used to identify services to which customers will most likely respond, and to personalize the offer through a direct communication channel they prefer (e.g., mobile, website, etc.). ${ }^{101}$

5. Differentiating the offer. Businesses should identify how their services and products are different from those of their competitors, and give customers compelling loyalty program offers that encourage them to choose their brand. ${ }^{102}$

6. Leveraging technology wisely. Businesses should let customers tell them how and how often they wish to be contacted, and avoid the temptation to overuse technologies that allow retailers to easily contact and advertise offers to their customers. Businesses should avert the risk of loyalty program customers' seeing offers as "spam". ${ }^{103}$

7. Considering non-monetary rewards. While financial incentives are the most important and powerful element of a successful loyalty program, non-monetary incentives hold the promise of helping build a relationship between customers and retailers. Businesses should consider rewarding loyalty program members for referrals or for interacting with the brand on social media. ${ }^{104}$

Some have been critical of the current state of loyalty programs, suggesting they have become dated and stale. ${ }^{105}$ Instead of fostering an honest and deep sense of customer loyalty, most programs are viewed as transactional. According to O'Dell, "A lot of people consider loyalty a one-dimensional experience: I spend money and I get points or I buy a certain number of things and I get something for that." ${ }^{106}$ O'Dell concludes that for loyalty programs to make themselves more attractive to customers (thereby increasing business and profits), they need to resist the temptation to focus on transactional means to encourage loyalty. ${ }^{107}$

Rather, O'Dell argues, loyalty programs need to find ways to establish and encourage "an emotional connection with the brand." ${ }^{108}$ They can do this by meeting the customers where they are. In an ever-changing media landscape, customers are increasingly participating in a variety of constantly shifting social media and web-based platforms where they feel comfortable and can fashion new identities and communities that suit their preferences and desires. O'Dell therefore recommends that loyalty programs enter into these digital spaces to find and serve their customers. ${ }^{109}$

At the beginning of the e-commerce boom, loyalty programs tried to adapt to this shifting social media landscape by extending their presence to the evolving online environment. Often, these efforts were designed as unique environments and loyalty benefits offered to the online environment. However, these efforts soon became more complex and diffuse as additional channels-or media modes such as mobile apps, and social media platforms such as Facebook and Twitter-further served to pull the loyalty membership away from the programs designed to serve them. 
Similarly to O'Dell, Retail TouchPoints recommends taking what they call an "Omnichannel" approach to "meeting customers where they are," but in a way that presents a cohesive and consistent branding face to the loyalty membership no matter the channel in which they encounter it. According to Matt Wise, the CEO of HelloWorld, "[r]ather than trying to reinvent loyalty strategies for each channel, retailers should consider their loyalty programs as a 'central engagement hub' for consumers." 110 These integrated, omnichannel loyalty programs would have the opportunity to create "a community for customers...[t]hat ...can then extend across Facebook, Twitter, Pinterest and whatever channel becomes hot in consumers' worlds." 111

One key element to success in the omnichannel approach is the delivery of relevant, personalized communications, no matter what platform the customer is using. According to the Bond Brand Loyalty report, their survey revealed a link between personalized, relevant communications from their loyalty program and member satisfaction. ${ }^{112}$ This finding suggests that some successful loyalty programs reach beyond transactional (monetary) benefits by providing relevant and personalized communications. In doing so, they provide the sense that members are valued customers, and provides them with an opportunity to associate an identity with, and a sense of attachment to, the program-plausibly strong contributors to customers' loyalty.

While some authors have lauded the effectiveness of tier-based rewards programs, a survey by COLLOQUY found that $32 \%$ of tier-based rewards system members do not know what tier they are on in their favorite rewards program-in fact, even simple tier systems such as those with gold, silver and bronze levels seem more to create confusion in customers than to inspire loyalty. ${ }^{113}$ Even more concerning, particularly for the transit industry, COLLOQUY's study showed that tier systems tend to reinforce-and perhaps even promote-economic inequities. According to their report, "the chasm between those able to reach the highest tiers and those trapped in the bottom tier-due to economic status-is widening. Consumers with incomes below $\$ 50,000$ a year are more than $50 \%$ less likely than those with incomes more than $\$ 100,000$ to make it to the high tier of a program. Moreover, $42 \%$ never make it out of the low tier." 114

These inequities can be even starker when customers are allowed to buy the loyalty membership benefits of the highest tier instead of "earning" them through the program's advertised loyalty system. Indeed, $33 \%$ of low-tier loyalty program respondents to COLLOUY's survey said they felt underappreciated for their participation in their program even though they participated whenever possible. ${ }^{115}$

Nevertheless, even with these flaws, tiered programs seem to be effective at motivating some of their members to change their spending habits. In order to achieve a higher tier status, COLLOQUY's study found, roughly half of respondents said they had either increased their spending or changed other purchasing behavior. ${ }^{116}$

\section{Recent Transit Loyalty Rewards Programs}

Several transit rewards and incentives programs, both pilots and larger-scale programs, have been implemented by transit agencies within the past 10 years or so. Walker 
expressed skepticism about the effectiveness of these programs, suggesting that transit agency time and resources would be better spent on enhancing operations and services rather than on potentially complicated and expensive transit rewards systems. ${ }^{117}$ These cases provide a more detailed investigation of the pitfalls and promises of transit loyalty and rewards programs.

This literature review identified the following loyalty and rewards programs implemented thus far in North America:

1. Montreal, Quebec: Société de transport de Montréal's STM Merci! Pilot Program

2. Minneapolis/St. Paul, Minnesota: Metro Transit's Ride to Rewards Program

3. San Francisco Bay Area, California: Bay Area Rapid Transit's BART Perks Pilot Program

4. South Florida: TriMet's Rail Rewards Program

5. Richmond, Virginia: RideGRTC Rewards Program

6. Eastern Contra Costa County, California: Tri Delta Transit's Frequent Rider Rewards Program

7. Los Angeles County, California: Metro's Metro Rewards Program

8. State of Connecticut: Connecticut Department of Transportation's Transit Rewards Program

9. Southeastern Pennsylvania: Southeastern Pennsylvania Transit Authority's SEPTA Perks Program

10.Sacramento, California: City of Sacramento, Sacramento Regional Transit, and Sacramento State University's Miles Program. 


\section{TRANSIT REWARDS PROGRAMS IN PRACTICE}

Using the 10 transit loyalty rewards and incentives programs identified and listed in the previous chapter, this research project developed in-depth case study profiles for the following three programs using a combination of research literature, popular and professional media sources, and telephone interviews with key actors involved in designing and operating these programs. Case studies were selected either because they were early-adopters (STM Merci! and Ride to Rewards) or because of the availability of data and research (BART Perks):

1. Montreal, Quebec: Société de transport de Montréal's STM Merci! Pilot Program

2. Minneapolis/St. Paul, Minnesota: Metro Transit's Ride to Rewards Program

3. San Francisco Bay Area, California: Bay Area Rapid Transit's (BART's) BART Perks Pilot Program.

\section{MONTREAL, QUEBEC: SOCIÉTÉ DE TRANSPORT DE MONTRÉAL'S STM MERCI! PROGRAM}

Montreal, Quebec's transit agency, the Société de transport de Montréal (STM), has developed one of the most fully-realized transit rewards program in North America thus far, the STM Merci! program. This began with STM's publicly-stated objective to increase ridership by $40 \%$ by $2020 .{ }^{118}$ While in the first five years, they were able to boost ridership by $15 \%$, mostly through large investments in rolling stock, ${ }^{119}$ ridership growth plateaued in the years that followed, well short of their $40 \%$ goal. At this point, STM was faced with the task of finding another path to boost ridership. ${ }^{120}$

In response, STM identified a range of initiatives, including marketing and service enhancements aimed at retaining existing riders (i.e., reducing churn), ${ }^{121,122}$ attracting new customers, improving brand recognition and awareness through marketing, improving information and value provided to customers, shifting ridership from peak to off-peak hours, increasing the frequency of public transit use, optimization of fares, ${ }^{123}$ increasing the ridership frequency among existing customers, and improving service, in part by "transforming the user experience." 124

\section{First Step: Rebranding STM's Image}

To address their ridership challenges, STM's new general manager at the time aggressively recruited talent from outside the transit industry to bring in new ideas. Pierre Bourbonnière was recruited as STM's new director of marketing from Air Canada, where he had been responsible for managing their customer rewards and loyalty programs. Under Bourbonnière, rebranding STM's image would become a central component of STM's reform efforts.

When Bourbonnière arrived at STM, he characterized it as a "traditional, old style transit agency." ${ }^{25}$ Bourbonnière quickly realized that STM's reputation among Montreal residents 
was poor. He illustrates the tough road ahead for STM at the time, when it came to improving their image and customer relations, with an anecdote. Before he arrived, Bourbonnière said that employees would hide their STM-branded jackets when they went home, because they would be harassed if they wore them in public. By the time that Bourbonnière left STM, in contrast, they were proud of where they worked and would openly wear their agency's logo in public. He suggests this dramatic change in the culture of STM and Montreal was due in part to their efforts to improve their brand and build customer loyalty. ${ }^{126}$

When he arrived at STM, Bourbonnière's first task was to spread awareness of the new capacity the agency was adding. From a marketing perspective, there were two possible approaches to carrying out this task. The more traditional method would be through mass advertising - television, radio, and print media advertising that would blanket the Montreal area, spreading the message indiscriminately to whomever was listening, whether they were potential transit riders or not. The other option, which was more attractive to Bourbonnière, was to invest in marketing directly to their customers as individuals. This was the path that would lead them to build STM Merci!. ${ }^{127}$

\section{Focusing: Reducing Ridership Churn Through Retention}

Rider retention became a particularly important focus for STM as they found that they were experiencing a $13 \%$ annual churn, with $13 \%$ of their smart card (OPUS) users ceasing to use their services over the course of a year, due to a combination of job changes, household relocations, or car purchases. ${ }^{128,129}$

Based on his experience at Air Canada, Bourbonnière's first proposal was to have "firstclass" rider lounges at STM's stations, but he soon came to realize that the idea was financially infeasible. ${ }^{130}$ However, digging deeper into their marketing surveys led to a key insight; Bourbonnière said they concluded that "[i]f we can just keep 2 percent to 4 percent of our riders each year," would go a long way towards meeting their ridership growth goals. ${ }^{131}$

Analysis suggested that this churn and reduced ridership overall was particularly pronounced among young adults, especially students who had recently purchased their first vehicle. STM targeted these users in order to "delay their decision to stop using public transport."132

Additional research on these young riders found that they were attracted to the perceived freedom offered by car use. This perception had led young riders to see car ownership as a rite of passage that made them feel grown up and conferred an aura of sex appeal. Cost was also a consideration for this young rider group. Recent college graduates could lease a low-cost vehicle for only a little more than what they spent on their monthly transit pass, and feel more "cool" in return. STM charged themselves with finding a way to compete with cars on these two issues; in other words, they wanted to find a way to make transit "cool" as well as cost-effective. ${ }^{133}$

Thus, STM began an agency-wide strategy to rebrand themselves, focusing their initial efforts on appealing to young commuters. Based on research showing that young adults tend 
to have high level of awareness of the environment, and that environmental consciousness is an important driver of transit use (in addition to price and convenience), STM designed and implemented a rider loyalty program in 2013 that was focused on building relationships with these young (and other) focused on appealing to their environmental sensibilities. These relationships were to be built with an emphasis on four elements: delivering the right product to the right person at the right place at the right time, all using smartphone technology as the primary channel of interaction with customers. ${ }^{134}$

\section{Operationalizing Personalization and Brand Loyalty: STM Merci!}

In order find an operational vision that would drive service improvements and ridership growth, STM held a series of consumer workshops that worked to define potential customer experiences while traveling on their system or using their online and mobile portals. From these scenarios, an "optimum use case" (with the ideal customer experience using STM's transit and online systems) was selected and translated into STM operational features and functions. ${ }^{135}$ This optimum use case envisioned STM as a

"personal concierge" for riders, not only for transportation (e.g., taxi's, bikes), but also for shopping, dining and events throughout Montreal. By matching our riders' real-time context (who, where, when, what) and their declared preferences and interests with offers from our merchant partners, we are able to provide them personalized, relevant geo-localized offers in real time straight to their mobile devices. ${ }^{136}$

This use case was then mapped to a set of operational capabilities that STM could then use identify potential solutions and seek out suitable vendors. One of these vendors, SAP, offered a set of "advanced cloud solutions" that STM could deploy to meet the optimum use case vision. As originally envisioned, SAP's system could help meet this vision by creating a personalized trip advisor application that would "[a]ccompany the customers on their trips and give them information about how they can improve their own trip experience." This system became the core of the STM Merci! mobile app, which was field tested over a three-year period from 2011 to $2014 .{ }^{137}$

To help optimize transit operations, STM decided to reach beyond the traditional confines of the transit system's property. Bourbonnière describes the program as one that gives benefits to riders throughout their daily lives, not just when riding transit, saying, "[a]s you walk around the city, we're rewarding you depending on how much you use public transit... We [provide offers] that are relevant to you as an individual." 138 

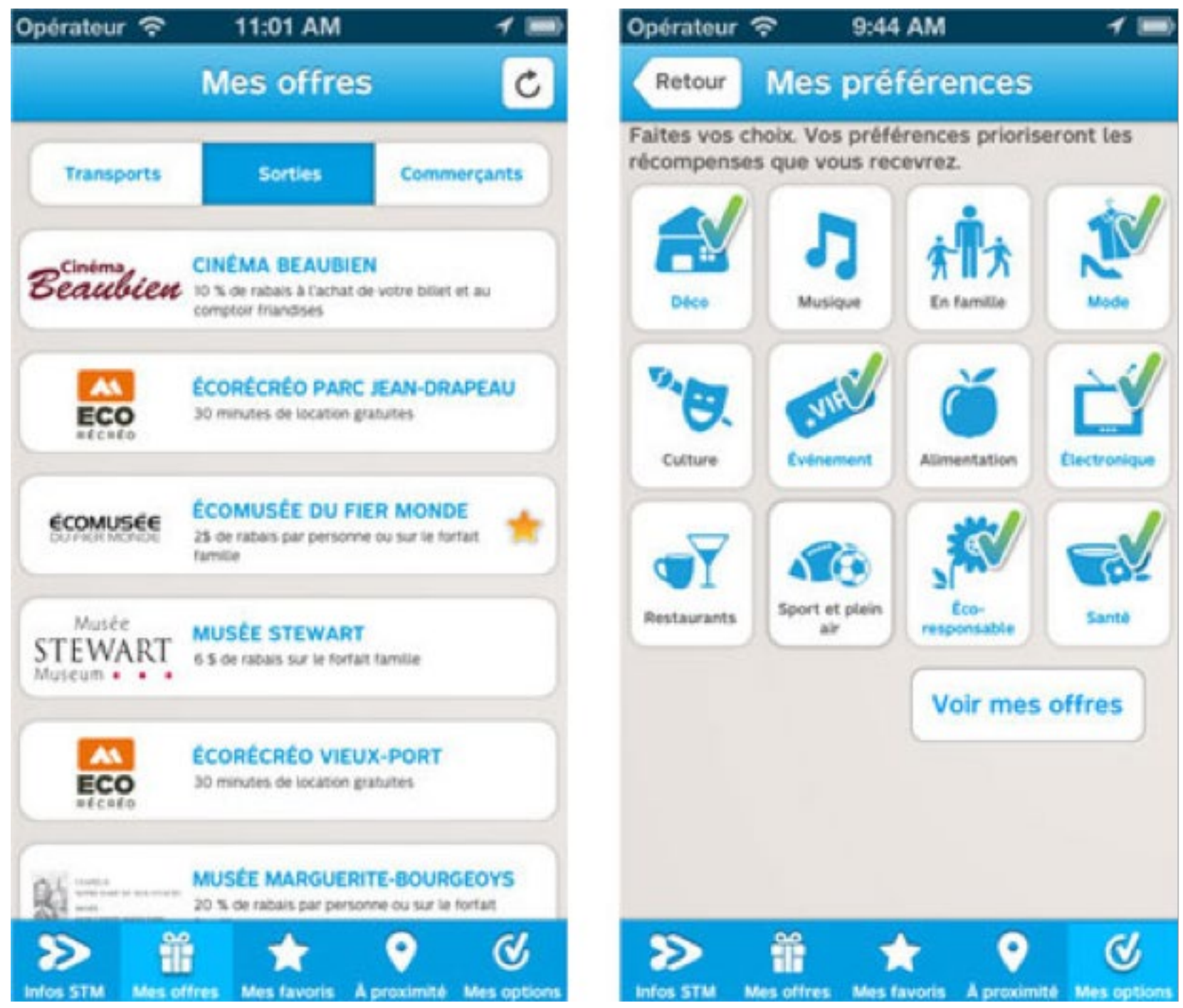

Figure 1. Screenshot of STM Merci! app showing a series of entertainment and shopping offers ("offres") to riders on the left and a set of user-defined preferences ("préférences") on the right.

Source: https://www.stevenvanbelleghem.com/blog/5-apps-that-have-changed-customer-engagement/

STM's smartphone-based app is central to this wide-ranging rewards program. The app records how often the user rides transit, monitors their location and provides rewards and product discounts for nearby retailers based on how much they ride transit. The system places riders into three rewards categories: a $50 \%$ discount on products for the top tier; a $30 \%$ discount for the second tier; and a 10\%-15\% discount for the third tier. ${ }^{139}$ The system then offers these benefits from their roughly 1,300 retail partners to their customers in each tier. Offers are also available to riders through an online search. Clark gives an example, where "a rider who wants to meet friends for a drink after work can look for a bar in the area that has offers. Using geo-location technology, the Merci app will provide him with recommendations, and show him how to get there using public transport." 140

The STM Merci! app tracked the location of its participants through their smartphones' GPS system, providing retail, restaurant, and entertainment offers that were personalized to the preferences of the user and their physical location within the Montreal metropolitan 
area. These real-time offers were sent to the user, based on the rider's destination on the transit system, as redeemable promotional codes for cultural, sporting, entertainment, and retail opportunities. ${ }^{141}$

By bringing this disparate collection of participants together and aligning their promotions towards rewarding transit ridership, STM Merci! served the city's goals of encouraging transit ridership ${ }^{142}$ while also enhancing economic activities within their service areas. ${ }^{143}$ STM reinforced environmental consciousness through their loyalty system by rewarding customers with "virtual trees" instead of simply with arbitrary points, representing the amount of environmental benefits (where one round-trip transit trip is equivalent to the environmental benefits provided by one tree over a year's period) their transit ridership has accrued. ${ }^{144}$

This ability to narrowly target and present offers to individuals according to their surroundings, time of day, and consumer history is a key element in this program's success. For example, a participant walking down the street in the morning will get an offer from the nearby coffee shop, but the same person walking down the same street in the evening will receive an offer from a local restaurant for dinner instead. ${ }^{145}$

The STM Merci! app also served as a platform for delivering other benefits to riders, beyond the rewards they receive at local retail and entertainment venues. For example, the app could alert individual riders of transit system delays and service interruptions, offer alternative means of transport, and recommend the best times to arrive at a station to get a seat, all using its geolocation capabilities. ${ }^{146}$

One of the biggest hurdles to implementation was Quebec's strict privacy laws. In summary, these laws said that companies cannot store customer data (where that data could be traced back to the customer) that are not critical to the mission of the organization, and even the customers' opting-in to the STM Merci! system was not considered sufficient justification for STM to keep their private information, at least not together. STM's solution to this problem involved the creation of two databases for two types of sensitive, private information for its users, the OPUS data and the personalized customer data (which would allow someone to connect the rider's identity), separated by a virtual firewall. ${ }^{147}$ This design prevented the data from being mixed and used without the customers' authorization from the customer; the only time the two databases are brought together is when the system creates a personalized offer for an individual customer. ${ }^{148}$

\section{STM Mercil's Outcomes}

In terms of direct effects of STM Merci! on travel behavior, Bourbonnière's group found that between $20 \%$ and $25 \%$ of STM Merci! participants increased their transit ridership over the system's three-year operating period. ${ }^{149}$ STM was also interested in expanding ridership outside of the commute hours for non-work purposes. Analysis showed that $57 \%$ of STM Merci! participants used transit for non-work trip purposes, and $27 \%$ brought a friend with them to go to an event using transit, responding to an offer from STM Merci!. All told, STM estimated that they gained close to an additional $\$ 100$ million over first three years of the pilot test from new ridership. ${ }^{150}$ 
The participating merchants also signaled their approval of the system through the $\$ 6$ million they paid STM in advertising fees when they sent out offers to the program's participants. Had the program continued beyond its three-year test period, STM estimated they would have reached annual revenues of more than $\$ 6$ million per year once the program reached maturity.

Verbal feedback from their participating merchant companies also indicated strong interest in STM Merci!. In fact, many of the companies said they were looking to implement these same features for all their customers (not just STM Merci! participants) eventually, but the infrastructure was not quite ready for them yet. Thus, STM was providing them with a way to do it much earlier than would have been possible otherwise. ${ }^{151}$

However, despite this enthusiasm, the most STM Merci! could accommodate in their pilot program was 75,000 rider participants, and while they did reach this level (another sign that their system was popular), they found that for most of their merchant participants, this was not enough and that they were eager for the system to continue and expand. Finally, just as STM was talking about expanding the program and continuing it beyond the three-year test period, the general manager who had hired Bourbonnière and backed the program left STM. Unfortunately, his replacement was not as interested in the program and chose not to support continuation. ${ }^{152}$

According to Bourbonnière, the loyalty system changed the way STM served its riders while transforming their relationships with local merchants, transportation partners, and entertainment providers. He told the authors,

Prior to the STM Merci! program, our relationship with riders was solely focused on traditional subway and bus services - to provide fare and routing information and enable ticket purchases. Our relationship with merchants was purely transactional-receiving rents from those operating and advertising within STMowned transit stations. With STM Merci!, these relationships [were] transformed. We [became] a 'personal concierge' for riders, not only for transportation (e.g., taxi's, bikes), but also for shopping, dining and events throughout Montreal. ${ }^{153}$

By matching our riders' real-time context (who, where, when, what) and their declared preferences and interests with offers from our merchant partners, we are able to provide them personalized, relevant geo-localized offers in real time straight to their mobile devices. Because our partners are now able to inform and influence riders at the moment of decision, we are creating a new, higher value channel for them, characterized by increased offer conversion rates and larger transaction sizes. Furthermore, we are able to provide them metrics on their promotions, and insights on their customers, so that they can optimize their marketing investments. ${ }^{154}$

This wide-reaching program design, spanning not just a person's daily commute, but potentially their shopping, recreation, and work activities as well, was influenced by loyalty programs from both the retail and airline travel sectors. Indeed, Bourbonnière had previously worked on loyalty programs for Air Canada, and once he arrived at STM, he 
employed an approach similar to frequent flier mileage programs from Air Canada for Montreal's transit system. ${ }^{155}$

Bourbonnière believes that SMT Merci! "has dramatically enhanced STM's image and brand with local merchants and riders." ${ }^{156}$ Within 48 hours of the app's launch, consumer adoption was high, earning it the \#1 spot on the Apple App store in Canada in the "Lifestyle" category, ${ }^{157}$ and over 20,000 downloads in the first two months. ${ }^{158}$ These consumer interactions were also significant in that consumers' acceptance rate for offers peaked at $47 \%$ in these early days. As the program matured, the top 10 offers enjoyed an overall acceptance rate of up to $33 \%$, with an average acceptance rate of $24 \%$. ${ }^{159}$

Over time, STM found that the system was resonating with customers-particularly with those young adults they initially targeted in their early marketing efforts. Ridership increased among young adult riders following the program's rollout, and their marketing research suggests that younger demographic groups saw cars as less "sexy" compared to before the program began. ${ }^{160}$

Increased rates of ridership were also found among STM Mercil's 20,000 users during the first 6 months of the pilot program's rollout. One quarter of these early adopters increased their use of public transportation. Intriguingly, $43 \%$ of these users were using transit for new reasons, no longer taking the bus or trains just for work trips, but also using transit increasingly for discretionary trips on weekends (e.g., shopping, entertainment). ${ }^{161}$ Making two-for-one offers to users for retail, food, and entertainment activities also yielded promising results, with almost half of recipients taking a friend along for the trip, increasing transit ridership and promising an opportunity for STM to retain these riders for future trips. ${ }^{162}$

Finally, STM sees the STM Merci! program as a channel through which they can make contact with riders and cultivate strong relationships with them. The program allows STM a means by which to identify riders who stop or reduce their transit use, and to understand their reasons for doing so. According to Bourbonnière, STM can now "contact them and ask them why" they stopped riding transit. They are also pursuing stronger rider relationships through messaging; Bourbonnière said that they are "trying to communicate that we're a dynamic organization that provides customers with the right choice," creating a more positive image for STM. ${ }^{163}$

\section{Long Term Potential}

If STM Merci! had continued, Bourbonnière had several ambitious ideas for how to expand the scope, scale, and benefits of the program. Firstly, the combined sales and travel behavior data collected through from their operations could eventually serve as a powerful supplement to the traditional travel behavior surveys used by transportation and land use planners. Eventually (and secondly), this marketing data could revolutionize the practice of travel behavior analysis, providing planners with the capability to accurately predict the movements and purchasing behaviors of specific market segments. These new data could also help land use planners and developers collaborate better to create data-driven, targeted incentives and policies to attract the right development for the right locations, with the right public services (such as transit) to serve them. ${ }^{164}$ 
Eventually, this combination of marketing and planning prowess could begin to address specific and seemingly intractable problems like the flight of young professionals from the central cities to the suburban fringe as they age and start families. By collecting data on and analyzing these narrow market segments, planners could potentially predict when and under what circumstances they would start to move out of urban neighborhoods and start driving more. Marketing programs and public services could then be coordinated to incentivize the delay the start of or completely stop these lifestyle and location changes. ${ }^{165}$

Taking these ideas a step further, Bourbonnière is currently working with a small Canadian city to design and implement an even more ambitious program modeled on STM Merci! that would reward transit riders not only for their pro-transit behaviors, but also for other pro-social and pro-environmental lifestyle choices. Using the GPS function on smartphones in combination with an STM Mercil-like app, participants will be rewarded for riding a bicycle, walking, and even such things composting their food waste instead of depositing in the landfill waste stream and reducing the use of water and electricity, together with other pro-social behaviors that have been out-of-reach of traditional policies and programs. In this way, many municipal services could be optimized through the use of targeted and "smart" incentives. ${ }^{166}$

\section{MINNEAPOLIS/ST. PAUL, MINNESOTA: METRO TRANSIT'S RIDE TO REWARDS PROGRAM}

In October 2010, Metro Transit in the Minneapolis/St. Paul (Twin Cities) region launched the Ride to Rewards program, the transit industry's first points-based frequent-rider loyalty program, ${ }^{167}$ whereby riders could earn points towards future bus and train rides when riding transit using Metro Transit's Go-To smart card. ${ }^{168,}{ }^{169}$ At this time, transit loyalty rewards programs were almost unheard of in North America, and as such, Ride to Rewards (along with STM Merci! which started at almost exactly the same time in Montreal) was in the vanguard. ${ }^{170}$ In the beginning, Metro Transit and its partner agencies in the Twin Cities region of Minnesota had been interested in incentivizing people to get out of their cars on air quality alert days. ${ }^{171} \mathrm{~A}$ start-up company called Transit Treasure approached Metro around this time, and proposed a rider rewards program using Metro's new smart card system to track both the ridership and consumer behaviors of its users. This dual-tracking capability was a key motivator for interesting both the merchants and Metro in Transit Treasure's proposal. ${ }^{172}$ Transit Treasure's proposed plan stated that they would do most of the implementation work for Ride to Rewards, with Metro Transit required to provide only minimal administrative support on their end. ${ }^{173}$

Fortunately, Metro Transit had recently completed implementation of their new "Go-To" transit smart card. This new system proved a useful starting point for building Ride to Rewards. ${ }^{174}$ Among other capabilities, the Go-To card gave Metro the ability to track people's riding activities, and by linking these movements to their purchasing behavior through participants' credit card transactions, the opportunity to provide merchants and Metro with a wealth of previously unavailable data linking travel behavior with trip destinations, activities and spending habits. While they were aware of the risks of pursing a program that was entirely new to American transit agencies, Metro Transit's general manager was interested in the potential benefits and willing to take those risks. ${ }^{175}$ 


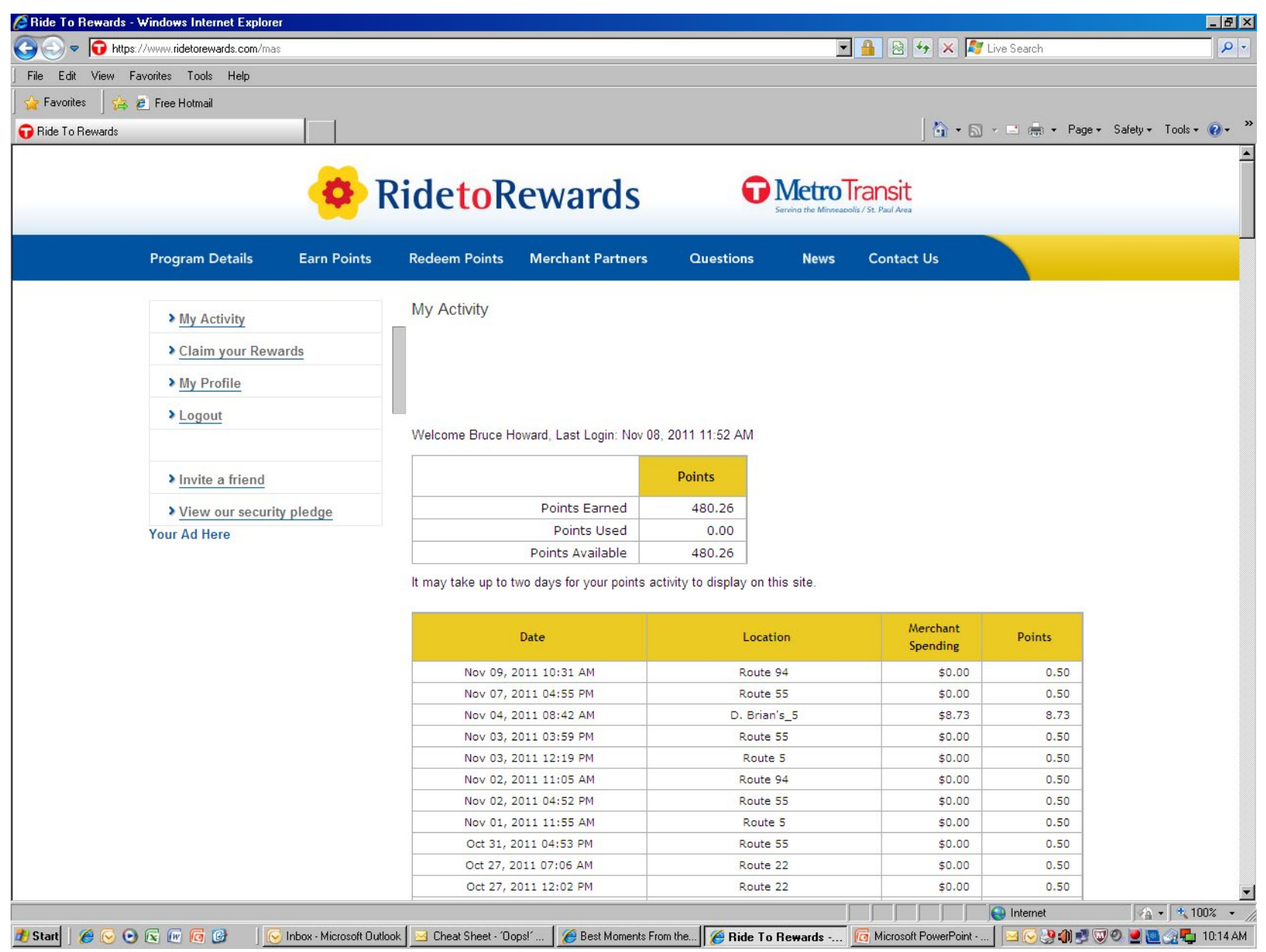

Figure 2. Metro Transit's Ride to Rewards Program Online Points Activity Screen

Source: Metro Transit \& Howard, Bruce. "Ride to Rewards." PowerPoint presentation slides dated November 14, 2011.

Once the program began, Transit Treasure would receive daily ridership data from Metro Transit's smart card database, count that day's points for each participant, and add them to the participants' accounts. ${ }^{176}$ Additional points could be earned by linking a credit or debit card to a Ride to Rewards account and using it to make purchases from merchant partners (see Figure 3). ${ }^{177}$ Customers who already rode Metro Transit at least three times a week, and who had a Go-To card but were not yet members of the Ride to Rewards program, were encouraged to sign up with webpage promotions that would read, "If you already ride transit three or more days a week, enroll and simply keep doing what you're doing!" 178

Meanwhile, on the merchant side, Transit Treasure had an agreement with a company with access to credit card purchase data. When each transaction was made by a rider/ participant at a partner merchant, the merchant would pay $3 \%$ to $4 \%$ of the purchase price to Transit Treasure. ${ }^{179}$ Using credit card data on each participant's purchases, Transit Treasure would add points to each rider's account when they made purchases at partner merchants. ${ }^{180}$ Initially, this was Transit Treasure's source of income from the program, but Transit Treasure would later claim that this revenue stream was insufficient to cover costs. ${ }^{181}$

These points could be converted to transit fares or redeemed for gift cards. Promotions 
would also advertise the program's free registration and participation benefits, including prize lotteries for airline tickets, hotel stays, tickets for sports events, and gift certificates, among other things. The program would update participants with direct emails about service updates and promotions. ${ }^{182}$

\section{How it Works}

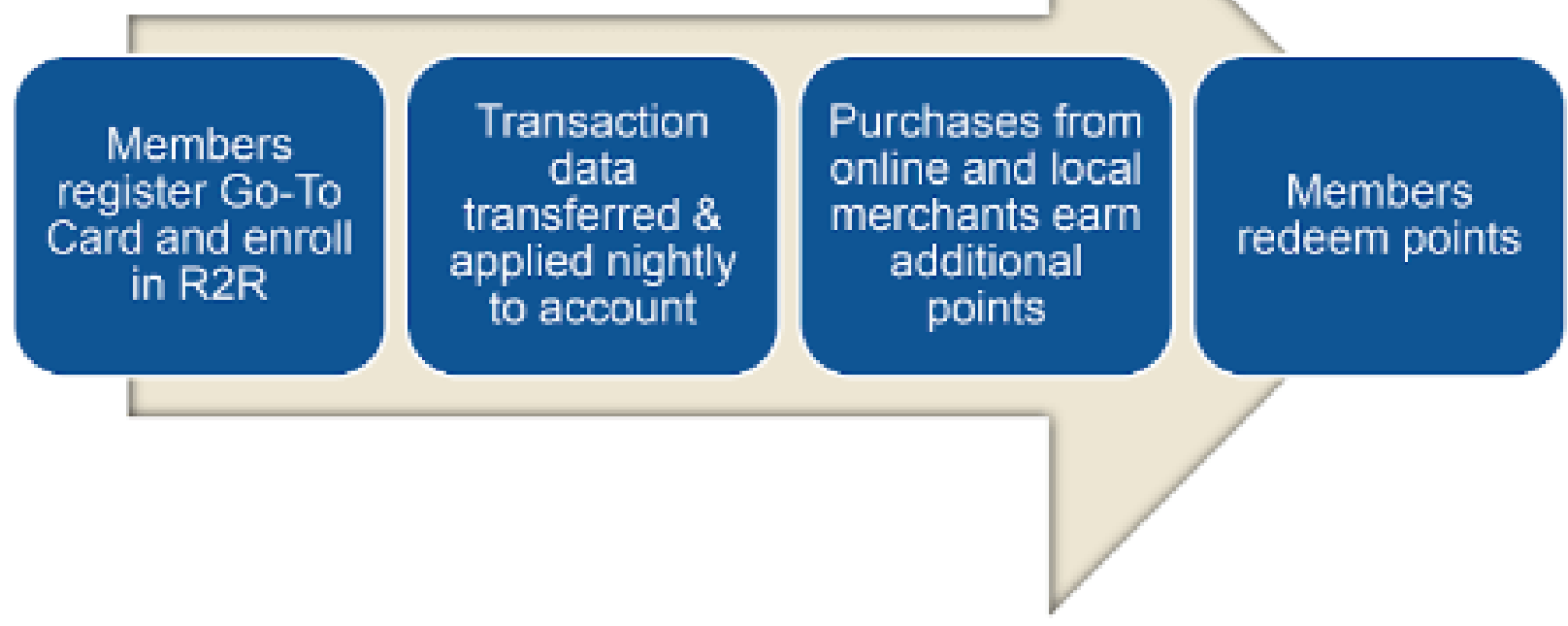

\section{T MetroTransit}

Figure 3. Metro Transit's Ride to Rewards Program Process

Source: https://www.customerinsightgroup.com/loyaltyblog/public-transit-reduce-churn-with-rewards

The Ride to Rewards program had several stated objectives, including:

1. Increasing transit riding frequency. ${ }^{183}$

2. Retention of current ridership. ${ }^{184,185}$

3. Attraction of new riders. ${ }^{186}$

4. Rewarding of riders with rides, products and services. ${ }^{187,} 188,189$

5. Enhancement of Metro Transit's relationships with its merchant partners. ${ }^{190}$

6. Encouragement for transit users in the greater Minneapolis area to use public transit as a consistent alternative to driving. ${ }^{191}$

7. Generation of increased tax revenues for Minnesotans. ${ }^{192}$

8. Reduction of local pollution due to auto emissions. ${ }^{193}$ 


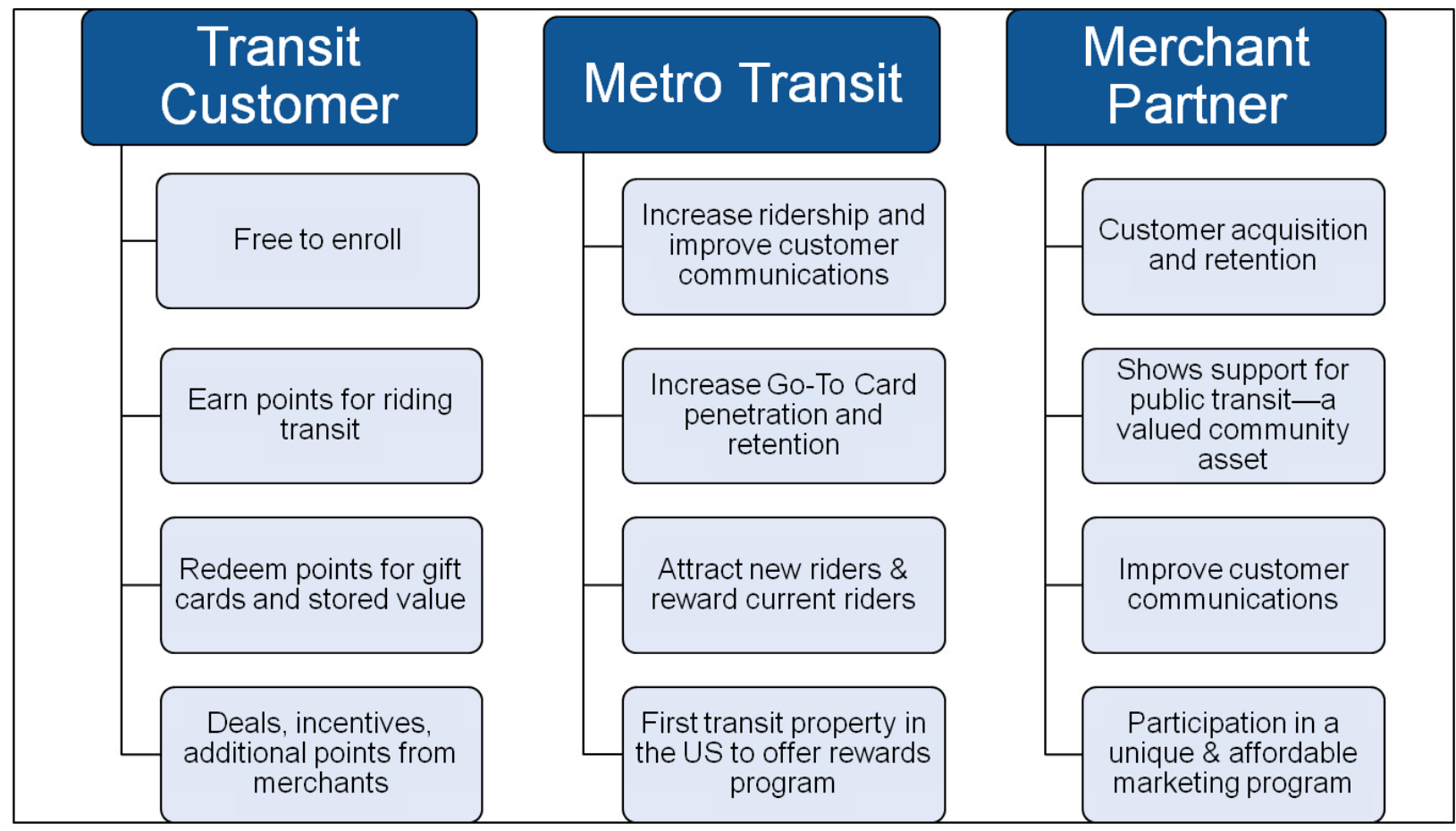

Figure 4. Metro Transit's Ride to Rewards Program Benefits

Source: Metro Transit \& Howard, Bruce. "Ride to Rewards." PowerPoint presentation slides dated November $14,2011$.

\section{Ride to Rewards' Outcomes}

By the end of the first year, more than 7,000 customers had enrolled in the Ride to Rewards program, ${ }^{194}$ and after three years they had over 20,000 members. ${ }^{195}$ Over $80 \%$ of the program's participants said they were more likely to use public transit because of it. While roughly half of the participants said they liked gift cards as their rewards, and almost $75 \%$ said they liked stored value. ${ }^{196}$

After three years of operation, the Ride to Rewards program was shut down, over concerns (from Metro Transit and Transit Treasure) about Transit Treasure's inability to continue to fund and operate the program. ${ }^{197}$ While successful on several levels-including the overcoming of technical hurdles and the signing up 20,000 of rider-participants-in other, crucial areas for the program's long-term survival, implementation and operations of the program fell short. Perhaps the most important shortcoming was the fact that the program did not get enough merchant partners to sign up and participate; in total only twelve merchants participated. ${ }^{198}$

In part, this low merchant participation rate may have been the result of the program's management structure. As mentioned above, Transit Treasure-a startup company, for which Ride to Rewards was the first client-was responsible for most of the administration and management of the program, including recruitment and retention of merchant partners. ${ }^{199}$ As a result, this small company did not have the institutional and organizational resources (e.g., marketing, financial administration, etc.) in place to run the program such as can be found in a larger company. While this incentive structure would seem at first glance to be appropriate, with Transit Treasure receiving greater revenues the more merchant 
partners they signed-up, the placement of so much of the weight of the program's success on a small start-up company may help explain the program's ultimate demise.

In the third year of the program, Transit Treasure said they were not earning enough revenue to continue. ${ }^{200}$ While Metro Transit agreed to subsidize the program in the hopes that it could continue, there simply weren't enough merchants participating and the program was shut down. ${ }^{201}$

According to Bruce Howard of Metro Transit, part of the reason why Transit Treasure was unable to attract more merchants was that they were too small of an organization; they simply did not have enough staff and resources to reach out to merchants in a systematic and sustained way. ${ }^{202}$ Instead, Transit Treasure spent some of their valuable time marketing their services to transit agencies in other metropolitan areas. Whether this was a wise use of their time and efforts is open to debate. After all, if they had been successful and had signed up new clients, these new revenue streams could have helped sustain the Ride to Rewards program as well. However, it seems reasonable to conclude that their focus on winning new contracts-a focus which did not result in new clients-took time away from their efforts to sign up new merchants for Ride to Rewards, leading to its demise.

In the end, Metro Transit wanted to take over the program from Transit Treasure, but their assessment of their own capabilities determined that they did not have the staff, expertise, or resources to do so. Of these, staff time was the biggest hurdle, since taking over Ride to Rewards would have required staff resources that would have left other high priority agency projects to suffer. ${ }^{203}$

\section{Long Term Risks and Potential}

In shutting down the program, Metro Transit made sure to give their existing 20,000 rider-participants a way to redeem the points they had accumulated in the program with transit fare credits and prizes. Unfortunately, Metro Transit perceived the Ride to Rewards program left their brand with a "black eye", even though they were able to pay off their participants' accumulated points. ${ }^{204}$

With mobile apps that track movements and ridership that could replace smart cards, the attraction of bringing back Ride to Rewards continues to grow. While Metro has an app that could serve as the launching pad to restarting the program, they are hesitant to do so after their last experience. ${ }^{205}$

\section{SAN FRANCISCO BAY AREA: BART PERKS PROGRAM}

The Bay Area Rapid Transit (BART) system in the San Francisco Bay Area recently instituted a pilot program, called BART Perks, to test whether incentives can encourage riders to shift their trips away from peak periods. ${ }^{206,} 207$ Ridership on their Transbay Tube corridor, connecting the East Bay cities to jobs in downtown San Francisco, has grown $75 \%$ between 2004 and 2016, and unfortunately, this corridor is now operating well beyond capacity in the peak periods, with BART's train car capacities running at 140 compared to their target of $117 .{ }^{208}$ 
Ordinarily, peak pricing would be the go-to solution for managing demand in the short term, since it will be years before BART's plans to increase Transbay Tube capacity are completed. However, since peak pricing is not currently under consideration by BART's Board of Directors, BART staff have sought to test other incentives to managing congestion in this corridor. ${ }^{209}$ BART looked to a system of incentives and gamification to coax riders out of the peak period. This approach was seen as a potentially more palatable alternative to peak pricing, since it rewards riders for desirable travel behavior (commuting by BART in the non-peak hours) rather than penalizing riders for undesirable travel behavior (commuting in the peak hours). ${ }^{210}$

BART and their partner, the San Francisco County Transportation Authority (SFCTA), designed BART Perks as a test for the potential of incentives programs to shift San Francisco-bound riders' journeys in the Transbay Tube away from the peak hour. ${ }^{211}$ So far, BART Perks has undergone two pilot tests, each targeted to determine the effects of incentives on specific rider market segments using different reward structures.

\section{First BART Perks Pilot Test}

The first test looked to determine both whether loyalty incentives would increase ridership on BART in general, and more specifically, whether these incentives would be attractive to riders in their most congested corridor, the Transbay Tube. ${ }^{212}$ These Transbay Tubetargeted incentives gave frequent riders points they could redeem through PayPal for small cash rewards. ${ }^{213}$

The pilot project ran for six months in 2017, with participants earning different numbers of points depending on the incentive plans being tested as well as on the rider's "status" in the program. Status was assigned to each participant based on the number of peak shoulder (the hours just before or just after the peak period) trips made. ${ }^{214}$ The total number of riders who enrolled and actively participated in the pilot test was 17,800 , with an additional 2,400 enrollees who never activated their accounts. ${ }^{215}$

The program tested two different incentive point systems, each designed to target incentives to specific trip type rider groups: long distance riders and all riders. . For the first four months of the program, incentives were calculated based on the distance they traveled on BART per day, at a rate of one point per mile for all travel on BART... ${ }^{216}$

In the second phase of the first pilot test, which took place during the final two months, points were no longer given on a per-mile basis, but rather on a per-trip basis, thereby removing the targeted incentive for long-distance BART riders. For both phases, the program also tested the effect of incentives on the transfer of riders' trips from the peak to the shoulder peak periods, by giving between three and six points per mile (depending on their program status) for participants who traveled during the shoulders of the peak (also referred to by BART as the so-called "Bonus Hours"). ${ }^{217}$ Participants also occasionally received additional special offers, called "bonus boxes," in order to test their sensitivity to different types and levels of incentives. During these periods, riders were offered between 20 and 500 points each to shift their Transbay Tube trip times from peak to shoulder peak periods. ${ }^{218}$ 
Participants' points were automatically entered into a random rewards generator (autoplay), which provided varying levels of reward. Participants could also choose to turn off autoplay and play their points in an online game or cash them out at a low dollar value. ${ }^{219}$

\section{BART Perks' First Pilot Test Goals and Outcomes}

The stated goals of the program were:

- Reduction of peak period and peak direction crowding and improvement of person throughput. A goal was to test the effects of rider incentives for shifting travel outside the morning rush, especially among peak period Transbay travelers. ${ }^{220}$

- Improvement of BART customer satisfaction. Crowding has led to historic declines in BART customer satisfaction. It was hoped that a travel incentives program could help improve satisfaction among participants. ${ }^{221}$

- Increase of employer support for flexible work schedules. BART Perks aimed to provide employers with technical resources to encourage adoption of flexible work hour policies. Workplace constraints have been identified as a top barrier to shifting travel out of peak periods. ${ }^{222}$

- Identification of implementation challenges and solutions. A goal is to apply any lessons learned to subsequent phases of the program, and to use them as guides to other regions considering similar programs. ${ }^{223}$

The program's evaluation provided analysis results for the performance of the first pilot test against each of these goals.

\section{1) Reduction of Peak Period and Peak Direction Crowding and Improvement of Person Throughput}

BART's efforts to target peak-direction commuters in the Transbay Tube were somewhat hampered by state sweepstakes law (covering the pilot test's Spin-to-Win component), which dictates that any California resident over 18 must be allowed to participate. This prevented BART from limiting their incentives to a select group of riders, in this case Transbay commuters. Therefore, BART sought to focus their marketing efforts at downtown San Francisco stations (served by the Transbay Tube), hoping to raise program enrollment among these Transbay commuters while remaining in compliance with state law. ${ }^{224}$

Unfortunately, peak period Transbay travelers were only $13 \%$ of pilot program participantslower than what BART had hoped for to test their responsiveness to incentives. ${ }^{225}$ However, the program exceeded expectations for participant sign-ups, suggesting there is substantial demand for this type of program among BART riders.

Over the course of their pilot program, BART Perks signed up nearly 18,000 registering for the program ${ }^{226}$-roughly 8,000 more than the 10,000 originally expected. ${ }^{227}$ According to BART, "[e]ach month Perks awarded an average of $\$ 35,000$ to all program participants, 
and roughly $\$ 210,000$ was awarded over the life of the program. Each month, rewards were transferred to participants' PayPal accounts."228

On average, the participants earned close to $\$ 3$ per month, with about 10 different participants per month being paid $\$ 100$ or more, from their participation in a "Spin to Win" game. Participants had two choices for playing the game: to manually enter their points into the lottery using the BART Perks website or to have them placed into the game automatically. The program's evaluation found that players who chose to manually play their points were more likely to shift their commute times to the shoulder-peak "bonus hours" than were participants who used the "autoplay" setting, ${ }^{229}$ suggesting that gamification of bonus programs may yield more powerful travel behavior changes.

Evaluation results suggested a small but meaningful decline in peak hour ridership during the morning commute riders, both among all BART riders and among those in the inbound (to San Francisco) who participated in the Perks program. Before the pilot test began, out of all BART Perks riders in the entire BART system, the share who rode during the AM peak hour was $14.3 \%$, while during the test period, $12.9 \%$ of BART Perks participants rode in the AM peak hour-a $9.8 \%$ decrease. ${ }^{230}$

Out of Transbay BART Perks riders inbound to San Francisco, 26.6\% rode during the AM peak hour while during the test period, the share of AM peak hour riders dropped to $23.7 \%$ - $10.9 \%$ decrease. Both declines suggest that BART Perks incentives were moderately successful at reducing AM peak hour riders, both among those inbound to San Francisco and among riders of the system as a whole. ${ }^{231}$

To see if these declines were also seen for all riders, and not just for BART Perks participants, in which case the changes would likely not be due to the program's incentives, BART compared these declines to the changes in ridership during the peak periods for all riders during the same timeframe. These comparisons revealed that during the same period, BART ridership systemwide during the AM peak hour increased by $0.3 \%$ (compared to a $9.8 \%$ decrease for BART Perks participants) and by $0.9 \%$ for AM peak hour Transbay riders (compared to $10.9 \%$ decrease for BART Perks participants). ${ }^{232}$

BART also estimated the number of trips that BART Perks participants shifted, finding that on average, 250 riders, or roughly two full train cars worth, shifted out of the AM peak hour systemwide on a typical weekday, and 180 riders shifted on the Transbay inbound route. As before, BART compared these BART Perks-only results to all riders on the system during the same time period. This analysis suggests these shifts are attributable to the BART Perks incentives and not due to other factors affecting all BART riders. ${ }^{233}$

However, while promising, the shift in peak-period trips had a small impact on crowding. Compared to the 170 peak-hour trips that BART Perks shifted to the shoulder peak periods, BART typically carries roughly 26,000 riders through the Transbay tube in the peak hour. To reach a $5 \%$ reduction (about 1,300 riders), BART Perks would need to scale up and/or improve the effectiveness of its incentives by more than sevenfold. ${ }^{234}$ 


\section{2) Improvement of BART Customer Satisfaction}

Overall, BART Perks participants were satisfied with the first pilot program, with roughly $70 \%$ of them saying they were either somewhat or very satisfied. However, they were also less satisfied with BART in general than were riders who didn't participate. BART attributes this finding to the fact that BART Perks participants tended to travel in the peak periods more, suggesting they were displeased with crowding rather than with the BART Perks program. If this is correct, then to the extent that full implementation of BART Perks would reduce peakhour ridership, it could also have a secondary benefit of improving customer satisfaction. ${ }^{235}$

\section{3) Increase of Employer Support for Flexible Work Schedules}

One of the rider outreach and recruitment efforts of the first pilot test of Perks involved an employer partnership program. Designed to increase rider participation in BART Perks (particularly among the crucial peak hour commuting rider market) while offering technical assistance to employers interested in adopting flexible work schedules, this effort was only partially successful. While 15 employers signed up as BART Perks Partners, only two requested technical assistance. ${ }^{236}$

So, while BART Perks Partners were helpful in promoting the Perks program to their employees, few were interested in getting help with building their flextime technical expertise. BART suggests that this lack of interest may be because those employers who signed-up for the program were already proficient in flexible work program administration. ${ }^{237}$

\section{4) Identification of Implementation Challenges and Solutions}

BART identified several key challenges to their first pilot Perks program, including: (1) difficulties recruiting riders who commuted during the peak hour period defined by the program (7:30 - 8:30); and (2) an incentives program that turned out to work better at attracting riders who were already traveling during the off-peak hour period than at motivating those riders who were traveling in the peak hour to time shift. ${ }^{238}$

Overall, BART concluded that many of these challenges could be addressed in future BART Perks tests by focusing their marketing and incentives programs on incentivizing riders to shift their riding times out of the peak hours and into the peak shoulder periods. For example, while the sweepstakes incentive was successful at incentivizing riders to shift their commute times, it was a somewhat blunt instrument, since California law would not allow BART to exclude riders who were not peak hour travelers, requiring instead that the sweepstakes component must be open to all. In the future, BART will need to weigh the benefits of a sweepstakes-based rewards program against this shortcoming. ${ }^{239}$

\section{Second BART Perks Pilot Test}

At the time of this report's writing, the second BART Perks pilot test is underway and nearing completion. According to BART, the second pilot test has taken the lessons learned from the first and is focusing the program's incentives more tightly on producing desired behavior changes. However, while the first test looked only at means to encourage peak shifts among BART commuters, this second test encourages both peak shift and off-peak 
ridership. The latter was included to test a means of responding to recent declines in evening and weekend ridership. Importantly, BART has decided to leave out the sweepstakes component features for this second test, due largely to the legal requirements from state regulators as discussed above, and to an inability to make their sweepstakes rewards customizable for individuals and target travel markets. ${ }^{240}$

\section{Mitigating Risks and Amplifying Potential}

One of BART's biggest operating challenges is to reduce crowding. Their first BART Perks pilot test addressed this challenge and showed that incentives can play a role in accomplishing this goal. However, BART also faced risks associated with the Perks program itself.

Firstly, starting a new program-particularly one that offers direct benefits to ridersruns the risk of raising rider expectations. Much like the Twin Cities' Ride to Rewards program, if those expectations are difficult to meet or if the program turns out to be too expensive then BART could have found itself in a position where they would have to decide between continuing a revenue-draining program or cancel it and suffer a "black eye" 241 in the view of the public. ${ }^{242}$ Instead of implementing a widespread program, therefore, BART decided to do a series of pilot tests where they could test the efficacy of various incentives while making it clear to the public as well as their partners that these programs were only temporary.

The first pilot test identified the risks of an inequitable rewards program-in this case, of giving rewards to commuters, since they were the target market segment for the study, over other, perhaps less affluent, off-peak riders. ${ }^{243}$ Since the purpose of the pilots was in part to identify equity considerations that would need to be considered before programs were made permanent, BART's experience suggest that future (and other agencies') programs need to analyze and address equity considerations. ${ }^{244}$

To further reduce financial risk, BART also sought and won federal grant funding to run these BART Perks pilot tests. ${ }^{245}$ By combining these outside funds with a clear, short-term pilot test period, BART was able to avoid the potential threat to their own operating budget.

Finally, in order to reduce the risk of a public image "whiplash" when the test period ended, BART capped the number of participants they would allow to take part in the program. ${ }^{246}$ This effectively reduced the number of riders who could feel let down once the test period ended.

\section{OTHER NOTABLE TRANSIT RIDERSHIP REWARDS PROGRAMS}

The South Florida Regional Transportation Authority's (SFRTA's) Tri-Rail system began its Rail Rewards program in 2010, with the original goal of increasing sales of monthly passes. The program gives special offers and coupons from South Florida-based restaurants, attractions and retailers with the purchase of a Tri-Rail Monthly Ticket. ${ }^{247}$ Bonnie Arnold, director of marketing for the SFRTA, reported that "We keep it fresh by constantly adding partners so, when customers log on at the first of the month, they 
never know what they may find." Shortly after its launch in September of 2010, the Rail Rewards website had more than 2,000 hits, indicating an encouraging level of interest by the riding public in this new service. ${ }^{248}$

In 2010, the TriDelta transit system in eastern Contra Costa County, California started a rider rewards program where loyal riders could earn free tickets. ${ }^{249,} 250$

In 2017, Richmond, Virginia's transit agency (the Greater Richmond Transit Company, or "GRTC") announced a combined transit rider and retail rewards program. This program is described in their press announcement: "By riding GRTC or shopping through GRTC Online Transit Store, riders can get discounts at local favorite merchants, like Capital Ale House, the Richmond Flying Squirrels, the Science Museum of Virginia, Segway of Richmond, and Burger Bach, to name a few."251 As of 2019, GRTC has 33 merchants participating in their program. ${ }^{252}$

Visalia Transit in Visalia, California has developed a similar program for their riders, offering discounts for local eateries to frequent riders and to new adopters of their smart card. ${ }^{253}$ As of 2019, Visalia Transit's rewards program had over 190 participating vendors providing discounts on food, entertainment, gym memberships, sports events, and other consumer goods and services. ${ }^{254}$ To design and implement their program, Visalia Transit hired a marketing firm, Archer \& Hound. The program is structured to reward monthly pass holders with discounts for participating local merchants, only requiring rewards monthly pass holders to "flash" their card at more than 120 local merchants and eateries to receive a pre-determined discount. In this way, the rewards program only benefits monthly pass users, encouraging other riders to purchase a monthly pass to take advantage of the discount rewards system. ${ }^{255}$

A more modest and focused program called Metro Rewards was implemented in Los Angeles County by the Los Angeles County Metropolitan Transportation Authority (LACMTA) for their transit expressway/BRT lines where frequent riders earn Metro passes, toll credits on the system. ${ }^{256}$

In 2018 Connecticut's Department of Transportation (CTDOT) launched their Transit Rewards Program, ${ }^{257}$ whereby transit passengers can show their transit ticket or pass to 50 participating merchants for discounts. ${ }^{258}$ Participants can redeem their rewards by showing their transit ticket, pass or a transit rewards coupon to these merchants when they make their purchases. ${ }^{259}$

Southeastern Pennsylvania Transit Authority's (SEPTA's) SEPTA Perks program offers rewards to their pass holders for discounts and other offers for dining, shopping, and entertainment from over 120 participating vendors from across their service area. ${ }^{260,} 261$

Begun in March of 2019 in the Sacramento, California region, Miles is a partnership between Sacramento Regional Transit, the City of Sacramento, and Sacramento State University using the mobile Miles app (see Miles app discussion in the next section). These Sacramento public entities are also using the app to reward "green" trips by walking, bicycling, transit and carpool with bonus points (in addition to standard trip points given for travel by any mode). ${ }^{262}$ 


\section{Private Sector Transit Rewards Programs}

\section{NuRide}

Ideas for implementing transit rewards programs have taken hold in the private sector as well. NuRide (now out of business) provided discounts at local retail establishments in eight cities across the U.S. for members who sign up and record their transit trips, carpooling rides, and work from home. Since their launch date in 2003, NuRide claimed to have signed up 152,000 members, and to have redeemed $\$ 5.7$ million in reward for more than 21 million transit rides, 23 million shared rides, 3.9 walking trips and 3.5 million bicycle trips. ${ }^{263}$

\section{Transit Treasure}

As described in the section on the Twin Cities region's Ride to Rewards program above, Transit Treasure was initially conceived as a private sector transit rider loyalty rewards implementation and administration contractor available to public transit agencies. Shortly thereafter, Transit Treasure expanded its business model to provide online retail discounts to transit riders around the country based on their self-reported transit ridership. Riders who reported at least 20 transit rides in a month earned 100 "Transit Miles" (points) and every dollar over $\$ 30$ spent with a participating online merchant would earn the riderparticipant an additional Transit Mile. Transit Mile points were redeemable as PayPal cash payments to riders. ${ }^{264}$ Transit Treasure has since gone out of business.

\section{Miles}

The Miles program rewards "[e]very trip...[e]very travel mode...[e]verywhere," automatically recorded by participants' mobile phone app. ${ }^{265}$ As of June of 2019, the Miles program offers discounts and other deals for 20 participating products, merchants and services. Users can make purchases either online or in-store. Users also receive push offers on their phones when they are in proximity to a vendor's physical location. ${ }^{266}$ 


\section{CONCLUSIONS AND IMPLICATIONS FOR FUTURE RESEARCH, POLICIES AND PRACTICE}

The initial inspiration for this research project was the idea that transit smart cards could be used as a tool for increasing transit ridership, retail sales in TODs and opportunities for retail development in TODs. This might work by adding customer loyalty rewards functionality to transit smart cards, for patronization of retail businesses located in TODs. Instead of providing loyalty rewards for each store or chain of stores, the smart card would provide loyalty rewards - in several possible forms including free transit ride credits, cash rewards, retail purchase discounts, sweepstakes rewards to name a few-to all transit riders who patronize TOD-based retail establishments. Additional rewards could be given to transit riders who live, work, and shop in TODs, and even to riders who take transit for specific shopping trips in TODs. In this way, smart cards and transit loyalty programs could become not only useful tools for increasing transit ridership, but also tools for targeted economic development of individual TODs, a means to increase economic opportunities and equity for low-income residents and shoppers in inner-city commercial zones, and in their most fully-realized expression, tools for regional planners to concentrate retail, services and housing in priority development areas consistent with smart growth planning principles.

From this initial inspiration, a plan was developed to gather research literature on the relationships between smart cards and transit ridership, between transit ridership and retail activities, and between retail sales and retail development in TODs. In the process of this literature search, several examples were identified of programs that have been implemented in North American transit agencies. In three of these cases-in Montreal, Canada; in Minneapolis/St. Paul, Minnesota; and in the San Francisco Bay Area in California-case study profiles were developed from a combination of source publication

materials, traditional and electronic media, and telephone interviews with program representatives.

These investigations revealed several important insights that can be helpful to researchers and practitioners in their efforts to design, establish, and optimize transit rewards and loyalty programs in the future:

1. The Lack of Retail-in-TODs Research. While there is a deep and wide gap in the research literature on what makes retail in TODs successful, several studies suggest that while challenging, TOD retail can be successful with the proper planning, collaboration, and data-driven incentives. This insight leads to two corollary ideas and recommendations. First, the gap needs filling; research on successful retail development in TODs is sorely needed. Second, the challenges to successful TOD retail may be at least partially overcome using the right incentives-perhaps incentives for transit ridership combined with TOD shopping that could be provided with a smart card-based loyalty rewards program.

2. The Lack of Research on Ridership Effects of Transit Smart Cards. Similar to the previous point, there is a lack of research not only on the effects of smart card programs on ridership, but also on the effects of different policies and of different types of smart card systems on ridership. For example, there is a lack of research 
on how different fare discount systems affect smart card adoption and consequent ridership.

3. The Importance of Rewarding Loyalty. The research literature and experts' practical experience agree that loyalty rewards and other incentives can play a significant role in shaping shopping and travel behavior. In particular, loyalty rewards are wellsuited to addressing the challenge of churn, where transit riders and shoppers alike tend to lose interest or become disenchanted with the services offered, moving on to another provider (or in the case of transit, another mode of travel).

4. Rebranding Transit's Image. STM Merci! presents a useful example of how loyalty, incentives, and the image of public transportation are intertwined. The future success of transit (if not its survival as an industry) may well depend on public transportation providers following STM's lead by addressing and influencing the perceptions of transit by marketing directly to key market segments (such as the young adult market). By combining retail rewards with sophisticated data collection, analysis and marketing techniques, STM Merci! points the way towards a new vision of how agencies can instill and encourage a new the public conception of a transitoriented, pro-environment, and socially-responsible lifestyle.

5. The Danger of Overreach. With all the success of STM Merci! and Ride to Rewards programs, they also serve as cautionary tales of the dangers to getting too far out in front of technical and institutional capabilities. Both programs reached new heights in making public transportation a more important and rewarding part of people's everyday lives. However, to the extent that both programs were successful, they were able to implement and build their programs due in no small measure to the vision and tenacity of a few key people-in STM's case, the general manager and Pierre Bourbonnière, and in the case of Metro Transit, the general manager and the head of Transit Treasure. In both cities and in both transit agencies, once these key players either lost interest in their programs or left their positions of influence, these efforts faltered and were ultimately shut down. In contrast to the experiences of these programs, BART has taken a much more cautious approach, limiting their BART Perks programs to short-term pilot test periods where they can gather data, perform analysis, and test options for implementation before committing their agency's reputation and resources.

6. The Potential of Incentives in Transit, TOD Retail and Beyond. Despite the ultimate demise of both the STM Merci! and Ride to Rewards programs, both teach valuable lessons about the potential for increasing transit ridership, retail sales, and ultimately the health and competitiveness of TOD retail by linking travel and consumer behaviors through incentives and loyalty rewards. And as Bourbonnière and the example of STM Merci! suggest, this may only be the beginning. If we consider the possibilities of expanding an STM Merci!-like program to offer incentives for all kinds of pro-environment and pro-social behaviors, a transit and retail rewards program could become an important tool for reforming and driving effectiveness gains in public services and government as a whole. 


\section{POLICY/PRACTICE RECOMMENDATIONS}

Policy and practice recommendations from this research include:

1. Develop more practice-driven research and experimentation on transit rider rewards and loyalty programs. In particular, research is needed to identify the best practices for the ownership, management and administration of loyalty rewards programs would be helpful to determine the degree public sector administration, contracting-out, or outright privatization yields the most effective and sustainable outcomes.

2. Market segment analysis is needed to understand the most effective rewards for the variety of transit riders according to socio-economic characteristics, lifestyle preferences, and corresponding transit system capabilities (both existing and future).

3. Transit agencies should consider looking beyond their customary approaches and methods to understanding and responding to the needs and their riders by, in part, seeking to build new and more personalized interactions and relationships with them. Loyalty rewards programs offer a good starting place for this ongoing and evolving effort. 


\section{ABBREVIATIONS AND ACRONYMS}

APTA American Public Transportation Association

BART Bay Area Rapid Transit

CTDOT Connecticut Department of Transportation

DVRPC Delaware Valley Regional Planning Commission

GRTC Greater Richmond Transit Company

LACMTA Los Angeles County Metropolitan Transportation Authority

MTA New York Metropolitan Transportation Authority

SFCTA San Francisco County Transportation Authority

STM Société de transport de Montréal

SFRTA South Florida Regional Transportation Authority

SEPTA Southeastern Pennsylvania Transit Authority

TOD Transit-Oriented Development

TNCs Transportation Network Companies 


\section{ENDNOTES}

1. Peter O. Muller, "Transportation and Urban Form," in The Geography of Urban Transportation, eds. Hanson, Susan \& Giuliano, Genevieve, (New York, NY: The Guilford Press 2004).

2. American Public Transportation Association (APTA) (2019), 2019 Public Transportation Fact Book: Appendix A Historical Tables (Washington, D.C.: American Public Transportation Association).

3. Robert Cervero et al., Transit Oriented Development in the United States: Experiences, Challenges, and Prospects (Washington, D.C.: Transit Cooperative Research Program, Report No. 102, 2004).

4. Marlon G. Boarnet and Randall Crane, Travel by Design: The Influence of Urban Form on Travel (New York, NY: Oxford University Press, 2001).

5. Michael Bernick and Robert Cervero, Transit Villages in the $21^{\text {st }}$ Century. (New York, NY: McGraw-Hill 1997).

6. Hank Dittmar and Gloria Ohland, The New Transit Town: Best Practices in TransitOriented Development (Washington, DC: Island Press 2004).

7. Christopher Ferrell et al., Livable Transit Corridors: Methods, Metrics and Strategies (Washington, DC: Transit Cooperative Research Program, Report No. 187, 2017).

8. Pamela Blais, Perverse Cities: Hidden Subsidies, Wonky Policy, and Urban Sprawl (Vancouver, BC: University of British Columbia Press 2010).

9. Frederick Guy, "Small, Local and Cheap? Walkable and Car-oriented Retail in Competition," Spatial Economic Analysis, 2013 Vol. 8, No. 4 (2013): 425-442.

10. Frederick Guy, "Small, Local and Cheap? Walkable and Car-oriented Retail in Competition," Spatial Economic Analysis, 2013 Vol. 8, No. 4 (2013): 425-442.

11. Frederick Guy, "Small, Local and Cheap? Walkable and Car-oriented Retail in Competition,” Spatial Economic Analysis, 2013 Vol. 8, No. 4 (2013): 425-442.

12. Jenny Schuetz, "Do Rail Transit Stations Encourage Neighbourhood Retail Activity?" Urban Studies, Vol. 52(14) (2015): 2699-2723.

13. Jill Grant and Katherine Perrott, "Where Is the Café? The Challenge of Making Retail Uses Viable in Mixed-use Suburban Developments," Urban Studies, 48(1) January (2011): 177-195.

14. Kevin Credit, "Transit-Oriented Economic Development: The Impact of Light Rail on New Business Starts in the Phoenix, AZ Region," Urban Studies, 2018, Vol. 55(13) 
(2017): 2838-2862.

15. 15 James Adam Lee, Retail Spaces in Mixed-Use Developments: Supporting Small Businesses and Creating Place in Seattle's Neighborhoods, Master of Urban Planning Thesis (Seattle, WA: University of Washington, 2018).

16. 16 Fujie Rao and Robert J. Summers, "Planning for retail resilience: Comparing Edmonton and Portland," Cities, Volume 58, October (2016): 97-106.

17. 17 Richard B. Ellison, et al. Electronic ticketing systems as a mechanism for travel behaviour change? Evidence from Sydney's Opal Card (Sydney, Australia: Institute of Transport and Logistics Studies, August 2016).

18. 18 Charles Sutter et al. 2009. "Impact of Implementation of New York Metropolitan Transportation Authority's MetroCard on Ridership and Revenue of Westchester County Bee-Line Bus System" (paper presented at the Transportation Research Board's $88^{\text {th }}$ Annual Meeting, Washington, D.C.: January 11-15, 2009).

19. Richard Thomas, "Urban Mobility Innovation / Nextcity," (PowerPoint presentation at the Global Technology Workshop. International Bridge, Tunnel and Turnpike Association, Normandy, France, 2013).

20. Delaware Valley Regional Planning Commission, SEPTA Transfer Pricing Analysis (Philadelphia, PA: Delaware Valley Regional Planning Commission, 2012).

21. "The 2017 Colloquy Loyalty Census," Colloquy, updated August 29, 2019, https:// www.the-cma.org/Contents/ltem/Display/327325.

22. According to Wax (2015), personal learning is defined as, "...achieving or moving towards mastery - of a body of knowledge, of a tool or system, of a particular task."

23. "The Science of Motivation," Dustin Wax, updated August 29, 2019, http://www. lifehack.org/articles/productivity/the-science-of-motivation.html.

24. "Can Public Transit Reduce Churn with Rewards Programs?," Sallie Burnett, Loyalty Blog: Fresh Ideas for Building Profitable Customer Relationships, updated August 29, 2019, https://www.customerinsightgroup.com/loyaltyblog/public-transit-reduce-churnwith-rewards.

25. Kari Watkins et al., Transit in the Era of Shared Mobility (Gainesville, FL: Southeastern Transportation Research, Innovation, Development, and Education Center (STRIDE) at the University of Florida Transportation Institute, January 2019).

26. Congressional Research Service, Trends in Public Transportation Ridership: Implications for Federal Policy(Washington, D.C.: Congressional Research Service, March 26, 2018). 
27. "Can Loyalty Programs Reverse Declining Public Transit Ridership?" Sallie Burnett, Forbes Agency Council, COUNCIL POST, updated August 29, 2019, https://www. forbes.com/sites/forbesagencycouncil/2018/12/21/can-loyalty-programs-reversedeclining-public-transit-ridership/\#4b2e46f4b44f.

28. American Public Transportation Association (APTA), Millennials \& Mobility: Understanding the Millennial Mindset, (Washington D.C.: American Public Transportation Association, 2013).

29. Congressional Research Service, Trends in Public Transportation Ridership: Implications for Federal Policy (Washington, D.C.: Congressional Research Service, March 26, 2018). https://crsreports.congress.gov/product/pdf/R/R45144.

30. "Can Public Transit Reduce Churn with Rewards Programs?," Sallie Burnett, Loyalty Blog: Fresh Ideas for Building Profitable Customer Relationships, updated August 29, 2019, https://www.customerinsightgroup.com/loyaltyblog/public-transit-reduce-churnwith-rewards.

31. Crowdtwist \& Brand Innovators, The Loyalty Evolution: Growing Investment and Multichannel Promise (New York, NY: Crowdtwist, 2016).

32. "A History of US Airline Deregulation Part 4 : 1979-2010: The Effects of Deregulation - Lower Fares, More Travel, Frequent Flier Programs" David M. Rowell, The Travel Insider, updated June 21, 2019, https://thetravelinsider.info/airlinemismanagement/ airlinederegulation2.htm.

33. "Can Public Transit Reduce Churn with Rewards Programs?," Sallie Burnett, Loyalty Blog: Fresh Ideas for Building Profitable Customer Relationships, updated August 29, 2019, https://www.customerinsightgroup.com/loyaltyblog/public-transit-reduce-churnwith-rewards.

34. Dea van Lierop and Ahmed El-Geneidy. "Is Having a Positive Image of Public Transit Associated with Travel Satisfaction and Continued Transit Usage? An Exploratory Study of Bus Transit." Public Transport, 10(2), August (2018): 241-256. doi: 10.1007/ s12469-018-0175-5.

35. "Who Wins With Transit Rider Loyalty Programs." Sandy Smith, Next City: Inspiring Better Cities: The Works, updated August 29, 2019, https://nextcity.org/daily/entry/ transit-rider-loyalty-programs-work.

36. "Can Public Transit Reduce Churn with Rewards Programs?," Sallie Burnett, Loyalty Blog: Fresh Ideas for Building Profitable Customer Relationships, updated August 29, 2019, https://www.customerinsightgroup.com/loyaltyblog/public-transit-reduce-churnwith-rewards.

37. Prudence Blake and others, "Customer Churn: The Missing Link in Public Transport Marketing" (paper presented at the Australasian Transport Research Forum 2017, 
Auckland, New Zealand, Proceedings 27-29, November 2017).

38. Adam Mason and others, "Market Churn in the British Rail Passenger Commuter and Leisure Markets" (paper presented at the European Transport Conference, Glasgow, United Kingdom, October 10-12, 2011).

39. "Can Public Transit Reduce Churn with Rewards Programs?," Sallie Burnett, Loyalty Blog: Fresh Ideas for Building Profitable Customer Relationships, updated August 29, 2019, https://www.customerinsightgroup.com/loyaltyblog/public-transit-reduce-churnwith-rewards.

40. Victoria Perk, Jennifer Flynn, and Joel Volinski. Transit Ridership, Reliability, and Retention (Washington, D.C.: U.S. Department of Transportation and National Center for Transit Research (NCTR), October 2008).

41. Valerie Webb, Customer Loyalty in the Public Transportation Context (Cambridge, MA: Massachusetts Institute of Technology, Master of Science Thesis in Transportation, February 2010).

42. Grahame R. Dowling, Corporate Reputation (New York, NY: Longman Publishing, 1994).

43. Maya Abou-Zeida and Moshe Ben-Akiva, "Travel mode switching: Comparison of findings from two public transportation experiments," Transport Policy, 24, (2012): 48-59.

44. Valerie Webb, Customer Loyalty in the Public Transportation Context (Cambridge, MA: Massachusetts Institute of Technology, Master of Science Thesis in Transportation, February 2010).

45. "Can Public Transit Reduce Churn with Rewards Programs?," Sallie Burnett, Loyalty Blog: Fresh Ideas for Building Profitable Customer Relationships, updated August 29, 2019, https://www.customerinsightgroup.com/loyaltyblog/public-transit-reduce-churnwith-rewards.

46. "La Société de transport de Montréal (STM)" Pierre Bourbonniere, Constellation Research, SuperNova Award Category: Digital Marketing Transformation and Next Generation Customer Experience, updated on August 29, 2019, https://www. constellationr.com/pierre-bourbonniere-la-soci-t-de-transport-de-montr-al-stm.

47. "Mobile Loyalty Accelerates Ridership for Montreal Transit." Cynthia Clark, ttec: Your Path to Customer Experience, August 29, 2019, https://www.ttec.com/articles/mobileloyalty-accelerates-ridership-montreal-transit.

48. "Can Public Transit Reduce Churn with Rewards Programs?," Sallie Burnett, Loyalty Blog: Fresh Ideas for Building Profitable Customer Relationships, updated August 29, 2019, https://www.customerinsightgroup.com/loyaltyblog/public-transit-reduce-churn- 
with-rewards.

49. "Can Public Transit Reduce Churn with Rewards Programs?," Sallie Burnett, Loyalty Blog: Fresh Ideas for Building Profitable Customer Relationships, updated August 29, 2019, https://www.customerinsightgroup.com/loyaltyblog/public-transit-reduce-churnwith-rewards.

50. Valerie Webb, Customer Loyalty in the Public Transportation Context (Cambridge, MA: Massachusetts Institute of Technology, Master of Science Thesis in Transportation, February 2010).

51. "Can Public Transit Reduce Churn with Rewards Programs?," Sallie Burnett, Loyalty Blog: Fresh Ideas for Building Profitable Customer Relationships, updated August 29, 2019, https://www.customerinsightgroup.com/loyaltyblog/public-transit-reduce-churnwith-rewards.

52. "Customer Loyalty Statistics: 2017 Edition.” Ashley Autry, updated August 29, 2019, https://blog.accessdevelopment.com/customer-loyalty-statistics-2017-edition\#lmktg.

53. "IRI Consumer Connect Survey Finds Consumers Hesitant to Open Wallets Despite Optimistic Financial Outlook," IRI, updated August 29, 2019, https://www. iriworldwide.com/en-US/News/Press-Releases/IRI-Consumer-Connect-SurveyFinds-Consumers-Hesita.

54. "Customer Loyalty Statistics: 2017 Edition." Ashley Autry, updated August 29, 2019, https://blog.accessdevelopment.com/customer-loyalty-statistics-2017-edition\#lmktg.

55. Nielsen, Get With the Program: Card-Carrying Consumer Perspectives on Retail Loyalty-Program Participation and Perks (New York, NY: The Nielsen Company, November 2016).

56. Nielsen, Get With the Program: Card-Carrying Consumer Perspectives on Retail Loyalty-Program Participation and Perks (New York, NY: The Nielsen Company, November 2016).

57. James McLaughlin and Daniel K. Boyle, "Transit Incentive Program for TransitDependent Riders," Transportation Research Record: Journal of the Transportation Research Board. Vol 1604, Issue 1, (1997).

58. Susan Shaheen et al., Smartphone Applications to Influence Travel Choices: Practices and Policies (Washington, D.C.: U.S. Department of Transportation Federal Highway Administration, Report No. FHWA-HOP-16-023, April 2016).

59. "Refer new drivers for double-sided rewards," Lyft, Lyft Help, updated on August 29, 2019, https://help.lyft.com/hc/en-us/articles/115012927907-Refer-new-drivers-fordouble-sided-rewards. 
60. "Refer new Drivers, Get Cash Rewards," Uber, updated August 29, 2019, https://www. uber.com/drive/partner-app/new-driver-referrals/.

61. Susan Shaheen et al., Smartphone Applications to Influence Travel Choices: Practices and Policies (Washington, D.C.: U.S. Department of Transportation Federal Highway Administration, Report No. FHWA-HOP-16-023, April 2016).

62. "Why Customers Participate in Loyalty Programs." Cameron Graham, updated August 29, 2019, http://technologyadvice.com/blog/marketing/why-customers-participateloyalty-programs/.

63. "Why Customers Participate in Loyalty Programs." Cameron Graham, updated August 29, 2019, http://technologyadvice.com/blog/marketing/why-customers-participateloyalty-programs/.

64. Nielsen, Get With the Program: Card-Carrying Consumer Perspectives on Retail Loyalty-Program Participation and Perks (New York, NY: The Nielsen Company, November 2016).

65. Susan Shaheen et al., Smartphone Applications to Influence Travel Choices: Practices and Policies (Washington, D.C.: U.S. Department of Transportation Federal Highway Administration, Report No. FHWA-HOP-16-023, April 2016).

66. Susan Shaheen et al., Smartphone Applications to Influence Travel Choices: Practices and Policies (Washington, D.C.: U.S. Department of Transportation Federal Highway Administration, Report No. FHWA-HOP-16-023, April 2016).

67. "NuRide," NuRide, updated on July 8, 2019, https://nuride.com/.

68. "StanfordAdds Walkers, Bikers to Incentive-Based Study to Relieve Traffic Congestion," Mark Golden, Stanford Report, updated August 29, 2019, https://news.stanford.edu/ news/2013/may/capri-walkers-bikers-051413.html.

69. "Metropia," Metropia, Updated August 29, 2019, http://metropia.com/metropia-drivingbetter-city.

70. Susan Shaheen et al., Smartphone Applications to Influence Travel Choices: Practices and Policies (Washington, D.C.: U.S. Department of Transportation Federal Highway Administration, Report No. FHWA-HOP-16-023, April 2016).

71. Susan Shaheen et al., Smartphone Applications to Influence Travel Choices: Practices and Policies (Washington, D.C.: U.S. Department of Transportation Federal Highway Administration, Report No. FHWA-HOP-16-023, April 2016).

72. Susan Shaheen et al., Smartphone Applications to Influence Travel Choices: Practices and Policies (Washington, D.C.: U.S. Department of Transportation Federal Highway Administration, Report No. FHWA-HOP-16-023, April 2016). 
73. "Why Customers Participate in Loyalty Programs." Cameron Graham, updated August 29, 2019, http://technologyadvice.com/blog/marketing/why-customers-participateloyalty-programs/.

74. "Badges? We Got Badges. We Love Badges! We Want More Badges!: How Foursquare imported a visual cue from the Boy Scout sash to the Web," Rob Walker, updated August 29, 2019, https://slate.com/human-interest/2011/07/foursquare-badges-howthe-social-networking-service-imported-a-visual-cue-from-the-boy-scout-sash-to-theweb.html.

75. "Why Customers Participate in Loyalty Programs." Cameron Graham, updated August 29, 2019, http://technologyadvice.com/blog/marketing/why-customers-participateloyalty-programs/.

76. "Why Customers Participate in Loyalty Programs." Cameron Graham, updated August 29, 2019, http://technologyadvice.com/blog/marketing/why-customers-participateloyalty-programs/.

77. Nielsen, Get With the Program: Card-Carrying Consumer Perspectives on Retail Loyalty-Program Participation and Perks (New York, NY: The Nielsen Company, November 2016).

78. Nielsen, Get With the Program: Card-Carrying Consumer Perspectives on Retail Loyalty-Program Participation and Perks (New York, NY: The Nielsen Company, November 2016).

79. Shelbi Augustus and Sean Kiernan, Gamification in Transportation (Los Angeles, CA: Los Angeles County Metropolitan Transportation Authority Information Technology Services Department, 2015).

80. "The Loyalty Report 2017," Bond Brand Loyalty, updated August, 29, 2019, https:// info.bondbrandloyalty.com/2017-loyalty-report.

81. Itaru Kuramoto and others, "Stand Up, Heroes!: Gamification for Standing People on Crowded Public Transportation" (paper presented at the International Conference of Design, User Experience, and Usability, Berlin, Germany: Springer 2013: 538-547).

82. Raman Kazhamiakin and others, "Using Gamification to Incentivize Sustainable Urban Mobility" (paper presented at the 2015 IEEE First International Smart Cities Conference (ISC2), Guadalajara, Mexico, October 25-28, 2015).

83. "Can Public Transit Reduce Churn with Rewards Programs?," Sallie Burnett, Loyalty Blog: Fresh Ideas for Building Profitable Customer Relationships, updated August 29, 2019, https://www.customerinsightgroup.com/loyaltyblog/public-transit-reduce-churnwith-rewards.

84. "Why Loyalty Marketing," Customer Insight Group, updated August 29, 2019, https:// 
www.customerinsightgroup.com/why-loyalty-marketing.

85. "Why Loyalty Marketing," Customer Insight Group, updated August 29, 2019, https:// www.customerinsightgroup.com/why-loyalty-marketing.

86. "Who Wins With Transit Rider Loyalty Programs." Sandy Smith, Next City: Inspiring Better Cities: The Works, updated August 29, 2019, https://nextcity.org/daily/entry/ transit-rider-loyalty-programs-work.

87. "Why Loyalty Marketing," Customer Insight Group, updated August 29, 2019, https:// www.customerinsightgroup.com/why-loyalty-marketing.

88. "Why Loyalty Marketing," Customer Insight Group, updated August 29, 2019, https:// www.customerinsightgroup.com/why-loyalty-marketing.

89. "25 Years Ago I Coined the Phrase 'Triple Bottom Line.' Here's why I Think It's Time to Rethink it," John Elkington, Harvard Business Review, updated August 29, 2019, https://hbr.org/2018/06/25-years-ago-i-coined-the-phrase-triple-bottom-line-hereswhy-im-giving-up-on-it.

90. "Why Loyalty Marketing," Customer Insight Group, updated August 29, 2019, https:// www.customerinsightgroup.com/why-loyalty-marketing.

91. "Why Loyalty Marketing," Customer Insight Group, updated August 29, 2019, https:// www.customerinsightgroup.com/why-loyalty-marketing.

92. "Why Loyalty Marketing," Customer Insight Group, updated August 29, 2019, https:// www.customerinsightgroup.com/why-loyalty-marketing.

93. Stefanie L. Boyer, Diane R. Edmondson, Brent Baker, and Paul Solomon, "Word-ofMouth Traditional and Covert Marketing: Comparative Studies," Academy of Marketing Studies Journal, 19(1), January 2015: 102-19.

94. "Why Loyalty Marketing," Customer Insight Group, updated August 29, 2019, https:// www.customerinsightgroup.com/why-loyalty-marketing.

95. "Why Loyalty Marketing," Customer Insight Group, updated August 29, 2019, https:// www.customerinsightgroup.com/why-loyalty-marketing.

96. "Why Loyalty Marketing," Customer Insight Group, updated August 29, 2019, https:// www.customerinsightgroup.com/why-loyalty-marketing.

97. Nielsen, Get With the Program: Card-Carrying Consumer Perspectives on Retail Loyalty-Program Participation and Perks. (New York, NY: The Nielsen Company, November 2016).

98. Nielsen, Get With the Program: Card-Carrying Consumer Perspectives on Retail 
Loyalty-Program Participation and Perks. (New York, NY: The Nielsen Company, November 2016).

99. Nielsen, Get With the Program: Card-Carrying Consumer Perspectives on Retail Loyalty-Program Participation and Perks. (New York, NY: The Nielsen Company, November 2016).

100. Nielsen, Get With the Program: Card-Carrying Consumer Perspectives on Retail Loyalty-Program Participation and Perks. (New York, NY: The Nielsen Company, November 2016).

101. Nielsen, Get With the Program: Card-Carrying Consumer Perspectives on Retail Loyalty-Program Participation and Perks. (New York, NY: The Nielsen Company, November 2016).

102. Nielsen, Get With the Program: Card-Carrying Consumer Perspectives on Retail Loyalty-Program Participation and Perks. (New York, NY: The Nielsen Company, November 2016).

103. Nielsen, Get With the Program: Card-Carrying Consumer Perspectives on Retail Loyalty-Program Participation and Perks. (New York, NY: The Nielsen Company, November 2016).

104. Nielsen, Get With the Program: Card-Carrying Consumer Perspectives on Retail Loyalty-Program Participation and Perks. (New York, NY: The Nielsen Company, November 2016).

105. "Relationships, Not Rewards, Are Key to Successful Loyalty Programs," Retail Touchpoints, updated August 29, 2019, https://www.retailtouchpoints.com/features/ special-reports/relationships-not-rewards-are-key-to-successful-loyalty-programs.

106. "Relationships, Not Rewards, Are Key to Successful Loyalty Programs," Retail Touchpoints, updated August 29, 2019, https://www.retailtouchpoints.com/features/ special-reports/relationships-not-rewards-are-key-to-successful-loyalty-programs.

107. "Relationships, Not Rewards, Are Key to Successful Loyalty Programs," Retail Touchpoints, updated August 29, 2019, https://www.retailtouchpoints.com/features/ special-reports/relationships-not-rewards-are-key-to-successful-loyalty-programs.

108. "Relationships, Not Rewards, Are Key to Successful Loyalty Programs," Retail Touchpoints, updated August 29, 2019, https://www.retailtouchpoints.com/features/ special-reports/relationships-not-rewards-are-key-to-successful-loyalty-programs.

109. "Relationships, Not Rewards, Are Key to Successful Loyalty Programs," Retail Touchpoints, updated August 29, 2019, https://www.retailtouchpoints.com/features/ special-reports/relationships-not-rewards-are-key-to-successful-loyalty-programs. 
110."Relationships, Not Rewards, Are Key to Successful Loyalty Programs," Retail Touchpoints, updated August 29, 2019, https://www.retailtouchpoints.com/features/ special-reports/relationships-not-rewards-are-key-to-successful-loyalty-programs.

111. "Relationships, Not Rewards, Are Key to Successful Loyalty Programs," Retail Touchpoints, updated August 29, 2019. https://www.retailtouchpoints.com/features/ special-reports/relationships-not-rewards-are-key-to-successful-loyalty-programs.

112."The Loyalty Report: 2014," Bond Brand Loyalty, updated August 29, 2019, http://info. bondbrandloyalty.com/the-2014-loyalty-report-us.

113. "Survey Finds That Three-Tiered Loyalty Program Structure is Outdated," Chain Store Age, updated August 29, 2019, https://www.colloquy.com/loyalty-strategies/goldsilver-bronze-rewards-system-is-outdated-confusing-study-says/.

114. "COLLOQUY Study Shows Nearly One-Third of Consumers Can't Identify Tier Status in Favorite Loyalty Rewards Program; 42\% Never Escape Lower Tier." Colloquy and BusinessWire, updated August 29, 2019, https://www.businesswire.com/news/ home/20140429006340/en/COLLOQUY-Study-Shows-One-Third-ConsumersCan\%E2\%80\%99t-Identify.

115. "COLLOQUY Study Shows Nearly One-Third of Consumers Can't Identify Tier Status in Favorite Loyalty Rewards Program; 42\% Never Escape Lower Tier." Colloquy and BusinessWire, updated August 29, 2019, https://www.businesswire.com/news/ home/20140429006340/en/COLLOQUY-Study-Shows-One-Third-ConsumersCan\%E2\%80\%99t-Identify.

116."COLLOQUY Study Shows Nearly One-Third of Consumers Can't Identify Tier Status in Favorite Loyalty Rewards Program; 42\% Never Escape Lower Tier." Colloquy and BusinessWire, updated August 29, 2019, https://www.businesswire.com/news/ home/20140429006340/en/COLLOQUY-Study-Shows-One-Third-ConsumersCan\%E2\%80\%99t-Identify.

117."Frequent-rider Discounts to Decongest the Peak?" Jarrett Walker, Human Transit, updated August 29, 2019, https://humantransit.org/2011/06/frequent-rider-discounts. html.

118. "La Société de transport de Montréal (STM)" Pierre Bourbonniere, Constellation Research, SuperNova Award Category: Digital Marketing Transformation and Next Generation Customer Experience, updated on August 29, 2019, https://www. constellationr.com/pierre-bourbonniere-la-soci-t-de-transport-de-montr-al-stm.

119. "Mobile Loyalty Accelerates Ridership for Montreal Transit." Cynthia Clark, ttec: Your Path to Customer Experience, August 29, 2019, https://www.ttec.com/articles/mobileloyalty-accelerates-ridership-montreal-transit.

120. "Mobile Loyalty Accelerates Ridership for Montreal Transit." Cynthia Clark, ttec: 
Your Path to Customer Experience, August 29, 2019, https://www.ttec.com/articles/ mobile-loyalty-accelerates-ridership-montreal-transit.

121. "Mobile Loyalty Accelerates Ridership for Montreal Transit." Cynthia Clark, ttec: Your Path to Customer Experience, August 29, 2019, https://www.ttec.com/articles/ mobile-loyalty-accelerates-ridership-montreal-transit.

122. "La Société de transport de Montréal (STM)" Pierre Bourbonniere, Constellation Research, SuperNova Award Category: Digital Marketing Transformation and Next Generation Customer Experience, updated on August 29, 2019, https://www. constellationr.com/pierre-bourbonniere-la-soci-t-de-transport-de-montr-al-stm.

123. "La Société de transport de Montréal (STM)" Pierre Bourbonniere, Constellation Research, SuperNova Award Category: Digital Marketing Transformation and Next Generation Customer Experience, updated on August 29, 2019, https://www. constellationr.com/pierre-bourbonniere-la-soci-t-de-transport-de-montr-al-stm.

124. "La Société de transport de Montréal (STM)" Pierre Bourbonniere, Constellation Research, SuperNova Award Category: Digital Marketing Transformation and Next Generation Customer Experience, updated on August 29, 2019, https://www. constellationr.com/pierre-bourbonniere-la-soci-t-de-transport-de-montr-al-stm.

125. Pierre Bourbonnière, (La Société de transport de Montréal's former Director of Marketing), interview by Christopher E. Ferrell May 28, 2019.

126. Pierre Bourbonnière, (La Société de transport de Montréal's former Director of Marketing), interview by Christopher E. Ferrell May 28, 2019.

127. Pierre Bourbonnière, (La Société de transport de Montréal's former Director of Marketing), interview by Christopher E. Ferrell May 28, 2019.

128. "Mobile Loyalty Accelerates Ridership for Montreal Transit." Cynthia Clark, ttec: Your Path to Customer Experience, August 29, 2019, https://www.ttec.com/articles/ mobile-loyalty-accelerates-ridership-montreal-transit.

129. "Cloud-Based Analytics Keeps Montreal's Buses Full and Ridership Growing," Carolyn D. Marsan, GCN: The Technology that Drives Government IT, updated August 29, 2019, https://gcn.com/articles/2014/01/17/montreal-metro.aspx.

130. Pierre Bourbonnière, (La Société de transport de Montréal's former Director of Marketing), interview by Christopher E. Ferrell May 28, 2019.

131. "Cloud-Based Analytics Keeps Montreal's Buses Full and Ridership Growing," Carolyn D. Marsan, GCN: The Technology that Drives Government IT, updated August 29, 2019, https://gcn.com/articles/2014/01/17/montreal-metro.aspx.

132. "Mobile Loyalty Accelerates Ridership for Montreal Transit." Cynthia Clark, ttec: 
Your Path to Customer Experience, August 29, 2019, https://www.ttec.com/articles/ mobile-loyalty-accelerates-ridership-montreal-transit.

133. "Mobile Loyalty Accelerates Ridership for Montreal Transit." Cynthia Clark, ttec: Your Path to Customer Experience, August 29, 2019, https://www.ttec.com/articles/ mobile-loyalty-accelerates-ridership-montreal-transit.

134. "Mobile Loyalty Accelerates Ridership for Montreal Transit." Cynthia Clark, ttec: Your Path to Customer Experience, August 29, 2019, https://www.ttec.com/articles/ mobile-loyalty-accelerates-ridership-montreal-transit.

135. "La Société de transport de Montréal (STM)" Pierre Bourbonniere, Constellation Research, SuperNova Award Category: Digital Marketing Transformation and Next Generation Customer Experience, updated on August 29, 2019, https://www. constellationr.com/pierre-bourbonniere-la-soci-t-de-transport-de-montr-al-stm.

136. "La Société de transport de Montréal (STM)" Pierre Bourbonniere, Constellation Research, SuperNova Award Category: Digital Marketing Transformation and Next Generation Customer Experience, updated on August 29, 2019, https://www. constellationr.com/pierre-bourbonniere-la-soci-t-de-transport-de-montr-al-stm.

137. "La Société de transport de Montréal (STM)" Pierre Bourbonniere, Constellation Research, SuperNova Award Category: Digital Marketing Transformation and Next Generation Customer Experience, updated on August 29, 2019, https://www. constellationr.com/pierre-bourbonniere-la-soci-t-de-transport-de-montr-al-stm.

138. "La Société de transport de Montréal (STM)" Pierre Bourbonniere, Constellation Research, SuperNova Award Category: Digital Marketing Transformation and Next Generation Customer Experience, updated on August 29, 2019, https://www. constellationr.com/pierre-bourbonniere-la-soci-t-de-transport-de-montr-al-stm.

139. "Montreal Transit app Rewards Riders With Personalized Offers." Nicole Schlosser, Metro: For Transit \& Motorcoach Business, updated August 29, 2019, http://www. metro-magazine.com/management-operations/article/211834/montreal-transit-apprewards-riders-with-personalized-offers.

140. "Mobile Loyalty Accelerates Ridership for Montreal Transit." Cynthia Clark, ttec: Your Path to Customer Experience, August 29, 2019, https://www.ttec.com/articles/ mobile-loyalty-accelerates-ridership-montreal-transit.

141. Elisa Tavilla, Transit Mobile Payments: Driving Consumer Experience and Adoption. (Boston, MA: Federal Reserve Bank of Boston, 2015).

142. According to Pierre Bourbonnière (May 28, 2019) telephone interview with Christopher E. Ferrell, STM Merci! added almost $\$ 100$ million in revenue from new ridership over the three years of the system's test period. 
143. Goodall, Warwick, Tiffany D. Fishman, Justine Bornstein, and Brett Bonthron. "The Rise of Mobility as a Service: Reshaping how Urbanites get Around." Deloitte Review. 20 (2017).

144. "Mobile Loyalty Accelerates Ridership for Montreal Transit." Cynthia Clark, ttec: Your Path to Customer Experience, August 29, 2019, https://www.ttec.com/articles/ mobile-loyalty-accelerates-ridership-montreal-transit.

145. "Mobile Loyalty Accelerates Ridership for Montreal Transit." Cynthia Clark, ttec: Your Path to Customer Experience, August 29, 2019, https://www.ttec.com/articles/ mobile-loyalty-accelerates-ridership-montreal-transit.

146. "Mobile Loyalty Accelerates Ridership for Montreal Transit." Cynthia Clark, ttec: Your Path to Customer Experience, August 29, 2019, https://www.ttec.com/articles/ mobile-loyalty-accelerates-ridership-montreal-transit.

147. "Cloud-Based Analytics Keeps Montreal's Buses Full and Ridership Growing," Carolyn D. Marsan, GCN: The Technology that Drives Government IT, updated August 29, 2019, https://gcn.com/articles/2014/01/17/montreal-metro.aspx.

148. "Mobile Loyalty Accelerates Ridership for Montreal Transit." Cynthia Clark, ttec: Your Path to Customer Experience, August 29, 2019, https://www.ttec.com/articles/ mobile-loyalty-accelerates-ridership-montreal-transit.

149. Pierre Bourbonnière, (La Société de transport de Montréal's former Director of Marketing), interview by Christopher E. Ferrell May 28, 2019.

150. Pierre Bourbonnière, (La Société de transport de Montréal's former Director of Marketing), interview by Christopher E. Ferrell May 28, 2019.

151. Pierre Bourbonnière, (La Société de transport de Montréal's former Director of Marketing), interview by Christopher E. Ferrell May 28, 2019.

152. Pierre Bourbonnière, (La Société de transport de Montréal's former Director of Marketing), interview by Christopher E. Ferrell May 28, 2019.

153. "La Société de transport de Montréal (STM)" Pierre Bourbonniere, Constellation Research, SuperNova Award Category: Digital Marketing Transformation and Next Generation Customer Experience, updated on August 29, 2019, https://www. constellationr.com/pierre-bourbonniere-la-soci-t-de-transport-de-montr-al-stm.

154. "La Société de transport de Montréal (STM)" Pierre Bourbonniere, Constellation Research, SuperNova Award Category: Digital Marketing Transformation and Next Generation Customer Experience, updated on August 29, 2019, https://www. constellationr.com/pierre-bourbonniere-la-soci-t-de-transport-de-montr-al-stm.

155. Pierre Bourbonnière, (La Société de transport de Montréal's former Director of 
Marketing), interview by Christopher E. Ferrell May 28, 2019.

156. "La Société de transport de Montréal (STM)" Pierre Bourbonniere, Constellation Research, SuperNova Award Category: Digital Marketing Transformation and Next Generation Customer Experience, updated on August 29, 2019, https://www. constellationr.com/pierre-bourbonniere-la-soci-t-de-transport-de-montr-al-stm.

157. "La Société de transport de Montréal (STM)" Pierre Bourbonniere, Constellation Research, SuperNova Award Category: Digital Marketing Transformation and Next Generation Customer Experience, updated on August 29, 2019, https://www. constellationr.com/pierre-bourbonniere-la-soci-t-de-transport-de-montr-al-stm.

158. "STM Merci: Data-Driven Customer Engagement Transforms Public Services." Pierre Bourbonniere, updated August 29, 2019, https://konference.pmdp.cz/uploads/_web/ prezentace2015/Pierre_Bourbonniere.pdf.

159. "La Société de transport de Montréal (STM)" Pierre Bourbonniere, Constellation Research, SuperNova Award Category: Digital Marketing Transformation and Next Generation Customer Experience, updated on August 29, 2019, https://www. constellationr.com/pierre-bourbonniere-la-soci-t-de-transport-de-montr-al-stm.

160. "Mobile Loyalty Accelerates Ridership for Montreal Transit." Cynthia Clark, ttec: Your Path to Customer Experience, August 29, 2019, https://www.ttec.com/articles/ mobile-loyalty-accelerates-ridership-montreal-transit.

161. "Mobile Loyalty Accelerates Ridership for Montreal Transit." Cynthia Clark, ttec: Your Path to Customer Experience, August 29, 2019, https://www.ttec.com/articles/ mobile-loyalty-accelerates-ridership-montreal-transit.

162. "Mobile Loyalty Accelerates Ridership for Montreal Transit." Cynthia Clark, ttec: Your Path to Customer Experience, August 29, 2019, https://www.ttec.com/articles/ mobile-loyalty-accelerates-ridership-montreal-transit.

163. "Mobile Loyalty Accelerates Ridership for Montreal Transit." Cynthia Clark, ttec: Your Path to Customer Experience, August 29, 2019, https://www.ttec.com/articles/ mobile-loyalty-accelerates-ridership-montreal-transit.

164. Pierre Bourbonnière, (La Société de transport de Montréal's former Director of Marketing), interview by Christopher E. Ferrell May 28, 2019.

165. Pierre Bourbonnière, (La Société de transport de Montréal's former Director of Marketing), interview by Christopher E. Ferrell May 28, 2019.

166. Pierre Bourbonnière, (La Société de transport de Montréal's former Director of Marketing), interview by Christopher E. Ferrell May 28, 2019.

167. Metropolitan Council, Regional Report: 2010 Performance Evaluation Report to the 
Minnesota Legislature. St. Paul, MN: Metropolitan Council (2011).

168. "Metro Transit Unveils Ride to Rewards Customer Loyalty Program" Metro Transit Press Release. November 2, 2010, https://www.metrotransit.org/TransitArticles/ Story . aspx ?pageid=247\&mid=395\&articleid=201.

169. Metropolitan Council, Regional Report: 2010 Performance Evaluation Report to the Minnesota Legislature, St. Paul, MN: Metropolitan Council (2011).

170. Bruce Howard (Director of Customer Services and Marketing, Metro Transit) interview by Christopher E. Ferrell, May 30, 2019.

171. Bruce Howard (Director of Customer Services and Marketing, Metro Transit) interview by Christopher E. Ferrell, May 30, 2019.

172. Bruce Howard (Director of Customer Services and Marketing, Metro Transit) interview by Christopher E. Ferrell, May 30, 2019.

173. Bruce Howard (Director of Customer Services and Marketing, Metro Transit) interview by Christopher E. Ferrell, May 30, 2019.

174. Bruce Howard (Director of Customer Services and Marketing, Metro Transit) interview by Christopher E. Ferrell, May 30, 2019.

175. Bruce Howard (Director of Customer Services and Marketing, Metro Transit) interview by Christopher E. Ferrell, May 30, 2019.

176. Bruce Howard (Director of Customer Services and Marketing, Metro Transit) interview by Christopher E. Ferrell, May 30, 2019.

177. "Metro Transit Unveils Ride to Rewards Customer Loyalty Program," Metro Transit, August 29, 2019. https://www.metrotransit.org/TransitArticles/Story.aspx?pageid=24 7\&mid=395\&articleid=201.

178. Ian Brelinsky et al. Privacy, SmartCards and the MBTA: A Policy Analysis of the MBTA's New Automated Fare Collection System, (Cambridge, MA: Massachusetts Institute of Technology, 2004).

179. Ian Brelinsky et al. Privacy, SmartCards and the MBTA: A Policy Analysis of the MBTA's New Automated Fare Collection System, (Cambridge, MA: Massachusetts Institute of Technology, 2004).

180. Bruce Howard (Director of Customer Services and Marketing, Metro Transit) interview by Christopher E. Ferrell, May 30, 2019.

181. Ian Brelinsky et al. Privacy, SmartCards and the MBTA: A Policy Analysis of the MBTA's New Automated Fare Collection System, (Cambridge, MA: Massachusetts 
Institute of Technology, 2004).

182. Ian Brelinsky et al. Privacy, SmartCards and the MBTA: A Policy Analysis of the MBTA's New Automated Fare Collection System, (Cambridge, MA: Massachusetts Institute of Technology, 2004).

183. "Can Public Transit Reduce Churn with Rewards Programs?," Sallie Burnett, Loyalty Blog: Fresh Ideas for Building Profitable Customer Relationships, updated August 29, 2019, https://www.customerinsightgroup.com/loyaltyblog/public-transit-reducechurn-with-rewards.

184. "Can Public Transit Reduce Churn with Rewards Programs?," Sallie Burnett, Loyalty Blog: Fresh Ideas for Building Profitable Customer Relationships, updated August 29, 2019, https://www.customerinsightgroup.com/loyaltyblog/public-transit-reducechurn-with-rewards.

185. Bruce Howard (Director of Customer Services and Marketing, Metro Transit) interview by Christopher E. Ferrell, May 30, 2019.

186. "Can Public Transit Reduce Churn with Rewards Programs?," Sallie Burnett, Loyalty Blog: Fresh Ideas for Building Profitable Customer Relationships, updated August 29, 2019, https://www.customerinsightgroup.com/loyaltyblog/public-transit-reducechurn-with-rewards.

187. "Can Public Transit Reduce Churn with Rewards Programs?," Sallie Burnett, Loyalty Blog: Fresh Ideas for Building Profitable Customer Relationships, updated August 29, 2019, https://www.customerinsightgroup.com/loyaltyblog/public-transit-reducechurn-with-rewards.

188. Bruce Howard (Director of Customer Services and Marketing, Metro Transit) interview by Christopher E. Ferrell, May 30, 2019.

189. Bruce Howard and Metro Transit, "Ride to Rewards," PowerPoint presentation slides November 14, 2011.

190. "Can Public Transit Reduce Churn with Rewards Programs?," Sallie Burnett, Loyalty Blog: Fresh Ideas for Building Profitable Customer Relationships, updated August 29, 2019, https://www.customerinsightgroup.com/loyaltyblog/public-transit-reducechurn-with-rewards.

191. Ian Brelinsky et al. Privacy, SmartCards and the MBTA: A Policy Analysis of the MBTA's New Automated Fare Collection System, (Cambridge, MA: Massachusetts Institute of Technology, 2004).

192. Ian Brelinsky et al. Privacy, SmartCards and the MBTA: A Policy Analysis of the MBTA's New Automated Fare Collection System, (Cambridge, MA: Massachusetts Institute of Technology, 2004). 
193. Ian Brelinsky et al. Privacy, SmartCards and the MBTA: A Policy Analysis of the MBTA's New Automated Fare Collection System, (Cambridge, MA: Massachusetts Institute of Technology, 2004).

194. Metropolitan Council, Regional Report: 2010 Performance Evaluation Report to the Minnesota Legislature. St. Paul, MN: Metropolitan Council (2011).

195. Bruce Howard (Director of Customer Services and Marketing, Metro Transit) interview by Christopher E. Ferrell, May 30, 2019.

196. "Can Public Transit Reduce Churn with Rewards Programs?," Sallie Burnett, Loyalty Blog: Fresh Ideas for Building Profitable Customer Relationships, updated August 29, 2019, https://www.customerinsightgroup.com/loyaltyblog/public-transit-reducechurn-with-rewards.

197. "Metro Transit Unveils Ride to Rewards Customer Loyalty Program," Metro Transit, August 29, 2019, https://www.metrotransit.org/TransitArticles/Story.aspx?pageid=24 $7 \& \mathrm{mid}=395 \&$ articleid $=201$.

198. Bruce Howard (Director of Customer Services and Marketing, Metro Transit) interview by Christopher E. Ferrell, May 30, 2019.

199. Bruce Howard (Director of Customer Services and Marketing, Metro Transit) interview by Christopher E. Ferrell, May 30, 2019.

200. Bruce Howard (Director of Customer Services and Marketing, Metro Transit) interview by Christopher E. Ferrell, May 30, 2019.

201. Bruce Howard (Director of Customer Services and Marketing, Metro Transit) interview by Christopher E. Ferrell, May 30, 2019.

202. Bruce Howard (Director of Customer Services and Marketing, Metro Transit) interview by Christopher E. Ferrell, May 30, 2019.

203. Bruce Howard (Director of Customer Services and Marketing, Metro Transit) interview by Christopher E. Ferrell, May 30, 2019.

204. Bruce Howard (Director of Customer Services and Marketing, Metro Transit) interview by Christopher E. Ferrell, May 30, 2019.

205. Bruce Howard (Director of Customer Services and Marketing, Metro Transit) interview by Christopher E. Ferrell, May 30, 2019.

206. San Francisco County Transportation Authority, Bay Area Rapid Transit District, and the U.S. Department of Transportation Federal Highway Administration, Lessons from Perks: Evaluation Findings from the BART Perks Test Program, (San Francisco, CA: San Francisco County Transportation Authority, June 2018). 
207. Ryan Greene-Roesel (Parking Program Manager, Bay Area Rapid Transit District) interview by Christopher E. Ferrell, May 31, 2019.

208. San Francisco County Transportation Authority, Bay Area Rapid Transit District, and the U.S. Department of Transportation Federal Highway Administration, Lessons from Perks: Evaluation Findings from the BART Perks Test Program, (San Francisco, CA: San Francisco County Transportation Authority, June 2018).

209. Ryan Greene-Roesel et al., "BART Perks: Using Incentives to Manage Transit Demand," Transportation Research Record. Washington, D.C.: National Academy of Sciences, Transportation Research Board (2018).

210. Ryan Greene-Roesel et al., "BART Perks: Using Incentives to Manage Transit Demand," Transportation Research Record. Washington, D.C.: National Academy of Sciences, Transportation Research Board (2018).

211.San Francisco County Transportation Authority, Bay Area Rapid Transit District, and the U.S. Department of Transportation Federal Highway Administration, Lessons from Perks: Evaluation Findings from the BART Perks Test Program, (San Francisco, CA: San Francisco County Transportation Authority, June 2018).

212. Ryan Greene-Roesel (Parking Program Manager, Bay Area Rapid Transit District) interview by Christopher E. Ferrell, May 31, 2019.

213. "What is BART Perks?" Bay Area Rapid Transit updated August 29, 2019. https:// www.bart.gov/guide/perks.

214. Ryan Greene-Roesel et al., "BART Perks: Using Incentives to Manage Transit Demand," Transportation Research Record. Washington, D.C.: National Academy of Sciences, Transportation Research Board (2018).

215. Ryan Greene-Roesel et al., "BART Perks: Using Incentives to Manage Transit Demand," Transportation Research Record. Washington, D.C.: National Academy of Sciences, Transportation Research Board (2018).

216. Ryan Greene-Roesel et al., "BART Perks: Using Incentives to Manage Transit Demand," Transportation Research Record. Washington, D.C.: National Academy of Sciences, Transportation Research Board (2018).

217. Ryan Greene-Roesel et al., "BART Perks: Using Incentives to Manage Transit Demand," Transportation Research Record. Washington, D.C.: National Academy of Sciences, Transportation Research Board (2018).

218. Ryan Greene-Roesel et al., "BART Perks: Using Incentives to Manage Transit Demand," Transportation Research Record. Washington, D.C.: National Academy of Sciences, Transportation Research Board (2018). 
219. Ryan Greene-Roesel et al., "BART Perks: Using Incentives to Manage Transit Demand," Transportation Research Record. Washington, D.C.: National Academy of Sciences, Transportation Research Board (2018).

220. Ryan Greene-Roesel et al., "BART Perks: Using Incentives to Manage Transit Demand," Transportation Research Record. Washington, D.C.: National Academy of Sciences, Transportation Research Board (2018).

221. Ryan Greene-Roesel et al., "BART Perks: Using Incentives to Manage Transit Demand," Transportation Research Record. Washington, D.C.: National Academy of Sciences, Transportation Research Board (2018).

222. Ryan Greene-Roesel et al., "BART Perks: Using Incentives to Manage Transit Demand," Transportation Research Record. Washington, D.C.: National Academy of Sciences, Transportation Research Board (2018).

223. Ryan Greene-Roesel et al., "BART Perks: Using Incentives to Manage Transit Demand," Transportation Research Record. Washington, D.C.: National Academy of Sciences, Transportation Research Board (2018).

224. Ryan Greene-Roesel et al., "BART Perks: Using Incentives to Manage Transit Demand," Transportation Research Record. Washington, D.C.: National Academy of Sciences, Transportation Research Board (2018).

225. Ryan Greene-Roesel et al., "BART Perks: Using Incentives to Manage Transit Demand," Transportation Research Record. Washington, D.C.: National Academy of Sciences, Transportation Research Board (2018).

226. "What is BART Perks?" Bay Area Rapid Transit updated August 29, 2019. https:// www.bart.gov/guide/perks.

227. "Incentives Shift BART Riders out of the Morning Rush," Bay Area Rapid Transit, updated August 29, 2019, https://www.bart.gov/news/articles/2017/news20170308.

228. "Incentives Shift BART Riders out of the Morning Rush," Bay Area Rapid Transit, updated August 29, 2019, https://www.bart.gov/news/articles/2017/news20170308.

229. San Francisco County Transportation Authority, Bay Area Rapid Transit District, and the U.S. Department of Transportation Federal Highway Administration, Lessons from Perks: Evaluation Findings from the BART Perks Test Program, (San Francisco, CA: San Francisco County Transportation Authority, June 2018).

230. Ryan Greene-Roesel et al., "BART Perks: Using Incentives to Manage Transit Demand," Transportation Research Record. Washington, D.C.: National Academy of Sciences, Transportation Research Board (2018).

231. Ryan Greene-Roesel et al., "BART Perks: Using Incentives to Manage Transit 
Demand," Transportation Research Record. Washington, D.C.: National Academy of Sciences, Transportation Research Board (2018).

232. Ryan Greene-Roesel et al., "BART Perks: Using Incentives to Manage Transit Demand," Transportation Research Record. Washington, D.C.: National Academy of Sciences, Transportation Research Board (2018).

233. Ryan Greene-Roesel et al., "BART Perks: Using Incentives to Manage Transit Demand," Transportation Research Record. Washington, D.C.: National Academy of Sciences, Transportation Research Board (2018).

234. Ryan Greene-Roesel et al., "BART Perks: Using Incentives to Manage Transit Demand," Transportation Research Record. Washington, D.C.: National Academy of Sciences, Transportation Research Board (2018).

235. Ryan Greene-Roesel et al., "BART Perks: Using Incentives to Manage Transit Demand," Transportation Research Record. Washington, D.C.: National Academy of Sciences, Transportation Research Board (2018).

236. Ryan Greene-Roesel et al., "BART Perks: Using Incentives to Manage Transit Demand," Transportation Research Record. Washington, D.C.: National Academy of Sciences, Transportation Research Board (2018).

237. Ryan Greene-Roesel et al., "BART Perks: Using Incentives to Manage Transit Demand," Transportation Research Record. Washington, D.C.: National Academy of Sciences, Transportation Research Board (2018).

238. Ryan Greene-Roesel et al., "BART Perks: Using Incentives to Manage Transit Demand," Transportation Research Record. Washington, D.C.: National Academy of Sciences, Transportation Research Board (2018).

239. Ryan Greene-Roesel et al., "BART Perks: Using Incentives to Manage Transit Demand," Transportation Research Record. Washington, D.C.: National Academy of Sciences, Transportation Research Board (2018).

240. Ryan Greene-Roesel (Parking Program Manager, Bay Area Rapid Transit District) interview by Christopher E. Ferrell, May 31, 2019.

241. Bruce Howard (Director of Customer Services and Marketing, Metro Transit) interview by Christopher E. Ferrell, May 30, 2019.

242. Ryan Greene-Roesel (Parking Program Manager, Bay Area Rapid Transit District) interview by Christopher E. Ferrell, May 31, 2019.

243. Ryan Greene-Roesel (Parking Program Manager, Bay Area Rapid Transit District) interview by Christopher E. Ferrell, May 31, 2019. 
244. Ryan Greene-Roesel (Parking Program Manager, Bay Area Rapid Transit District) interview by Christopher E. Ferrell, May 31, 2019.

245. Ryan Greene-Roesel (Parking Program Manager, Bay Area Rapid Transit District) interview by Christopher E. Ferrell, May 31, 2019.

246. Ryan Greene-Roesel (Parking Program Manager, Bay Area Rapid Transit District) interview by Christopher E. Ferrell, May 31, 2019.

247. "TransitAgencies Cultivate Customer Base to Grow Rail Ridership,"Alex Roman, Metro Magazine, August 29, 2019, http://www.metro-magazine.com/rail/article/211462/ transit-agencies-cultivate-customer-base-to-grow-rail-ridership?page $=2$.

248. "TransitAgencies Cultivate Customer Base to Grow Rail Ridership,"Alex Roman, Metro Magazine, August 29, 2019, http://www.metro-magazine.com/rail/article/211462/ transit-agencies-cultivate-customer-base-to-grow-rail-ridership?page $=2$

249. "Tri Delta Transit introduces Free Rides with Frequent Rider Rewards," Tri Delta Transit, 511 Contra Costa, updated August 29, 2019, https://511contracosta.org/tridelta-transit-introduces-free-rides-with-frequent-rider-rewards/?force=desktop.

250. "Tri Delta Transit introduces Free Rides with Frequent Rider Rewards," Tri Delta Transit, 511 Contra Costa, updated August 29, 2019, https://511contracosta.org/tridelta-transit-introduces-free-rides-with-frequent-rider-rewards/?force=desktop.

251. "GRTC Launches Rider Reward Program: RideGRTC Rewards," GRTC Transit System, updated August 29, 2019, http://ridegrtc.com/news-initiatives/pressreleases/grtc-launches-rider-reward-program-ridegrtc-rewards.

252. "RideGRTC REWARDS Program Overview," GRTC Transit System, updated August 29, 2019, http://ridegrtc.com/fares/find-rewards/.

253. "A Rewarding Ride: Visalia Transit Inaugurates Rewards Plan for Bus Riders." Eric Woomer, updated August 29, 2019, http://www.valleyair.org/recent_news/News_ Clippings/2010/In\%20the\%20News\%2008-03-10.pdf.

254. "Participating Retailers," Visalia Transit, updated August 29, 2019, https://www. visaliarewards.com/participating-retailers/.

255. "Rider Rewards," Archer \& Hound, updated August 29, 2019, https://www. archerandhound.com/blog/casestudy/rider-rewards/.

256. "Metro Rewards," Metro, updated August 29, 2019, https://www.metro.net/riding/ rideshare/rewards/.

257. "DOT Unveils Transit Rewards Program," Sean Teehan, updated August 29, 2019, https://www.hartfordbusiness.com/article/dot-unveils-transit-rewards-program. 
258. "Loyalty Programs and Gamification in Public Transit," Paul Comfort, Mass Transit, updated August 29, 2019, https://www.masstransitmag.com/technology/passengerinfo/article/13000010/loyalty-programs-and-gamification-in-public-transit.

259. "DOT Unveils Transit Rewards Program," Sean Teehan, updated August 29, 2019, https://www.hartfordbusiness.com/article/dot-unveils-transit-rewards-program.

260. "Loyalty Programs and Gamification in Public Transit," Paul Comfort, Mass Transit, updated August 29, 2019, https://www.masstransitmag.com/technology/passengerinfo/article/13000010/loyalty-programs-and-gamification-in-public-transit.

261. "Perks for all!," Southeast Pennsylvania Transportation Authority, updated August 29, 2019, https://iseptaphilly.com/perks.

262. "Miles - Get Rewarded for Your Commute \& Travel," Sacramento Regional Transit District, updated August 29, 2019, https://www.sacrt.com/apps/miles-get-rewardedfor-your-commute-travel/.

263. "NuRide", NuRide, updated on July 8, 2019, https://nuride.com/.

264. “Transit Treasure: Ride CTA, buy things, get cash," Kevin O'Neil, CTA Tatler, updated August 29, 2019, http://www.chicagonow.com/cta-tattler/2011/09/transit-treasureride-cta-buy-things-get-cash/.

265. "Frequent Flyer Program for Ground Transportation," Miles, updated August 29, 2019, https://www.getmiles.com/?c=email_sac_rt\&_branch_match_ id $=623945397987426768$

266. "Partners," Miles, updated August 29, 2019, https://www.getmiles.com/partner. 


\section{BIBLIOGRAPHY}

Abou-Zeida, Maya, and Moshe Ben-Akiva.. "Travel mode switching: Comparison of findings from two public transportation experiments." Transport Policy, 24, 48-59, 2012. doi: 10.1016/j.tranpol.2012.07.013.

American Public Transportation Association (APTA). Millennials \& Mobility: Understanding the Millennial Mindset. Washington D.C.: American Public Transportation Association, 2013.

American Public Transportation Association (APTA). 2019 Public Transportation Fact Book: Appendix A Historical Tables. Washington D.C.: American Public Transportation Association, 2019.

Archer \& Hound. "Rider Rewards." August 29, 2019. https://www.archerandhound.com/ blog/casestudy/rider-rewards/.

Augustus, Shelbi, and Sean Kiernan. Gamification in Transportation. Los Angeles, CA: Los Angeles County Metropolitan Transportation Authority Information Technology Services Department, 2015.

Autry, Ashley, and Access. "Customer Loyalty Statistics: 2017 Edition." August 29, 2019. https://blog.accessdevelopment.com/customer-loyalty-statistics-2017edition\#Imktg.

Bay Area Rapid Transit. "What is BART Perks?" August 29, 2019. https://www.bart.gov/ guide/perks.

Bay Area Rapid Transit. "Incentives Shift BART Riders out of the Morning Rush" August 29, 2019. https://www.bart.gov/news/articles/2017/news20170308.

Bernick, Michael, and Robert Cervero. Transit Villages in the $21^{\text {st }}$ Century. New York, NY: McGraw-Hill, 1997.

Blais, Pamela. Perverse Cities: Hidden Subsidies, Wonky Policy, and Urban Sprawl. Vancouver, BC: University of British Columbia Press, 2010.

Blake, Prudence, Graham Currie, Alexa Delbos, and Chris Lowe. "Customer Churn: The Missing Link in Public Transport Marketing." Auckland, NZ: Australasian Transport Research Forum 2017 Proceedings 27-29 November 2017, 2012.

Boarnet, Marlon G., and Randall Crane. Travel by Design: The Influence of Urban Form on Travel. New York, NY: Oxford University Press, 2001.

Bond Brand Loyalty. “The Loyalty Report 2017.” August 29, 2019. https://info. bondbrandloyalty.com/2017-loyalty-report. 
Bond Brand Loyalty. "The Loyalty Report: 2014." August 29, 2019. http://info. bondbrandloyalty.com/the-2014-loyalty-report-us.

Bourbonnière, Pierre. "La Société de transport de Montréal (STM)" Constellation Research, SuperNova Award Category: Digital Marketing Transformation and Next Generation Customer Experience, August 29, 2019. https://www.constellationr. com/pierre-bourbonniere-la-soci-t-de-transport-de-montr-al-stm.

Bourbonnière, Pierre. "STM Merci: Data-Driven Customer Engagement Transforms Public Services." August 29, 2019. https://konference.pmdp.cz/uploads/_web/ prezentace2015/Pierre_Bourbonniere.pdf.

Boyer, Stefanie L., Diane R. Edmondson, Brent Baker, and Paul Solomon. "Word-ofMouth Traditional and Covert Marketing: Comparative Studies." Academy of Marketing Studies Journal. 19(1), January 2015: 102-19.

Burnett, Sallie. "Can Loyalty Programs Reverse Declining Public Transit Ridership?" Forbes Agency Council COUNCIL POST. August 29, 2019. https://www.forbes. $\mathrm{com} /$ sites/forbesagencycouncil/2018/12/21/can-loyalty-programs-reversedeclining-public-transit-ridership/\#4b2e46f4b44f.

Burnett, Sallie. "Can Public Transit Reduce Churn with Rewards Programs?" Loyalty Blog: Fresh Ideas for Building Profitable Customer Relationships. August 29, 2019. https://www.customerinsightgroup.com/loyaltyblog/public-transit-reducechurn-with-rewards.

Brelinsky, lan, Brian Myhre, Jennifer Novosad, and Chris Suarez. Privacy, SmartCards and the MBTA: A Policy Analysis of the MBTA's New Automated Fare Collection System, Cambridge, MA: Massachusetts Institute of Technology, 2004.

Cervero, Robert, Steven Murphy, Christopher Ferrell, Natasha Goguts, and Yu-Hsin Tsai. Transit Oriented Development in the United States: Experiences, Challenges, and Prospects. Transit Cooperative Research Program, Report No. 1022004.

Chain Store Age. "Survey Finds That Three-Tiered Loyalty Program Structure is Outdated." August 29, 2019. https://www.colloquy.com/loyalty-strategies/goldsilver-bronze-rewards-system-is-outdated-confusing-study-says/.

Clark, Cynthia. "Mobile Loyalty Accelerates Ridership for Montreal Transit." ttec, Your Path to Customer Experience, August 29, 2019. https://www.ttec.com/articles/ mobile-loyalty-accelerates-ridership-montreal-transit.

Colloquy and BusinessWire. "COLLOQUY Study Shows Nearly One-Third of Consumers Can't Identify Tier Status in Favorite Loyalty Rewards Program; 42\% Never Escape Lower Tier." August 29, 2019. https://www.businesswire.com/news/ home/20140429006340/en/COLLOQUY-Study-Shows-One-Third-ConsumersCan\%E2\%80\%99t-Identify. 
Colloquy. "The 2017 Colloquy Loyalty Census." August 29, 2019. https://www.the-cma. org/Contents/ltem/Display/327325.

Comfort, Paul. "Loyalty Programs and Gamification in Public Transit." Mass Transit, August 29, 2019. https://www.masstransitmag.com/technology/passenger-info/ article/13000010/loyalty-programs-and-gamification-in-public-transit.

Congressional Research Service. "Trends in Public Transportation Ridership: Implications for Federal Policy." Washington, D.C.: Congressional Research Service, March 26, 2018.

Credit, Kevin. "Transit-Oriented Economic Development: The Impact of Light Rail on New Business Starts in the Phoenix, AZ Region." Urban Studies, Vol. 55(13) (2018): 2838-2862. doi: 10.1177/0042098017724119.

Crowdtwist \& Brand Innovators. The Loyalty Evolution: Growing Investment and Multichannel Promise. New York, NY: Crowdtwist, 2016.

Customer Insight Group. "Why Loyalty Marketing." August 29, 2019. https://www. customerinsightgroup.com/why-loyalty-marketing.

Delaware Valley Regional Planning Commission. SEPTA Transfer Pricing Analysis. Philadelphia, PA: Delaware Valley Regional Planning Commission, 2012.

Dittmar, Hank, and Gloria Ohland. The New Transit Town: Best Practices in TransitOriented Development. Washington, DC: Island Press, 2004. doi: 10.5860/ choice.42-0424.

Dowling, Grahame R. (1994) Corporate Reputation. Longman Publishing, New York.

Elkington, John and Harvard Business Review. "25 Years Ago I Coined the Phrase 'Triple Bottom Line.' Here's why I Think It's Time to Rethink it." August 29, 2019. https:// hbr.org/2018/06/25-years-ago-i-coined-the-phrase-triple-bottom-line-heres-whyim-giving-up-on-it.

Ellison, Richard B., Adrian B. Ellison, Stephen P. Greaves, and Breno Sampaio. "Electronic Ticketing Systems as a Mechanism for Travel Behaviour Change? Evidence from Sydney's Opal Card." Sydney, Australia: Institute of Transport and Logistics Studies. August 2016.

Ferrell, Christopher, Bruce Appleyard, Mathew Taecker, Courtney Armusewicz, Chris Allen, Caleb Schroder, Ardy Beheshti, and Evan Casey. Livable Transit Corridors: Methods, Metrics and Strategies. Washington, DC: Transit Cooperative Research Program, Report No. 187 (TCRP H-45), 2017.

Golden, Mark. "Stanford Adds Walkers, Bikers to Incentive-Based Study to Relieve Traffic Congestion." Stanford Report, August 29, 2019. https://news.stanford.edu/ 
news/2013/may/capri-walkers-bikers-051413.html.

Goodall, Warwick, Tiffany D. Fishman, Justine Bornstein, and Brett Bonthron.. "The Rise of Mobility as a Service: Reshaping how Urbanites get Around." Deloitte Review. 20, 2017.

Graham, Cameron, "Why Customers Participate in Loyalty Programs." August 29, 2019. http://technologyadvice.com/blog/marketing/why-customers-participate-loyaltyprograms/.

Grant, Jill \& Katherine Perrott. "Where Is the Café? The Challenge of Making Retail Uses Viable in Mixed-use Suburban Developments." Urban Studies, 48(1) (January 2011): 177-195. doi: 10.1177/0042098009360232.

Greene-Roesel, Ryan, Joe Castiglione, Camille Guiriba, and Mark Bradley. "BART Perks: Using Incentives to Manage Transit Demand," Transportation Research Record. Washington, D.C.: National Academy of Sciences, Transportation Research Board 2018. doi: $10.1177 / 0361198118792765$.

GRTC Transit System. "GRTC Launches Rider Reward Program: RideGRTC Rewards." August 29, 2019. http://ridegrtc.com/news-initiatives/press-releases/grtc-launchesrider-reward-program-ridegrtc-rewards.

GRTC Transit System. "RideGRTC REWARDS Program Overview." August 29, 2019. http://ridegrtc.com/fares/find-rewards/.

Guy, Frederick (2013). "Small, Local and Cheap? Walkable and Car-oriented Retail in Competition." Spatial Economic Analysis, Vol. 8, No. 4 (2013): 425-442.

IRI. "IRI Consumer Connect Survey Finds Consumers Hesitant to Open Wallets Despite Optimistic Financial Outlook." August 29, 2019. https://www.iriworldwide.com/ en-US/News/Press-Releases/IRI-Consumer-Connect-Survey-Finds-ConsumersHesita.

Kazhamiakin, Raman, Annapaola Marconi, Mirko Perillo, Marco Pistore, Giuseppe Valetto, Luca Piras. Francesco Avesani, and Nicola Perri. "Using gamification to incentivize sustainable urban mobility." Paper presented at the 2015 IEEE First International Smart Cities Conference (ISC2), Guadalajara, Mexico, October 2528, 2015. doi: 10.13140/RG.2.1.2622.2166.

Kuramoto, Itaru, Takuya Ishibashi, Keiko Yamamoto, and Yoshihiro Tsujino. "Stand Up, Heroes!: Gamification for Standing People on Crowded Public Transportation." Paper presented at the International Conference of Design, User Experience, and Usability, Berlin, Germany: Springer 2013: 538-547. doi: 10.1007/978-3-64239241-2_59.

Lee, James A. "Retail Spaces in Mixed-Use Developments: Supporting Small Businesses 
and Creating Place in Seattle's Neighborhoods." Seattle, WA: Master of Urban Planning Thesis, University of Washington, 2018.

Marsan, Carolyn D. "Cloud-Based Analytics Keeps Montreal's Buses Tull and Ridership Growing." GCN: The Technology that Drives Government IT, August 29, 2019. https://gcn.com/articles/2014/01/17/montreal-metro.aspx.

Mason, Adam, John Segal, and Ben Condry. "Market Churn in the British Rail Passenger Commuter and Leisure Markets." Paper presented at the European Transport Conference, Glasgow, United Kingdom, October 10-12, 2011.

McLaughlin, James and Daniel K. Boyle. "Transit Incentive Program for TransitDependent Riders." Transportation Research Record: Journal of the Transportation Research Board. Vol 1604, Issue 1, 1997. doi: 10.3141/1604-16.

Metro Transit. "Metro Transit Unveils Ride to Rewards Customer Loyalty Program." August 29, 2019. https://www.metrotransit.org/TransitArticles/Story.aspx?pageid= $247 \& \mathrm{mid}=395 \&$ articleid $=201$.

Metro. "Metro Rewards." August 29, 2019. https://www.metro.net/riding/rideshare/ rewards/.

Howard, Bruce, and Metro Transit. "Ride to Rewards." PowerPoint presentation slides dated November 14, 2011.

Metropia. "Total Mobility." August 29, 2019. http://metropia.com/metropia-driving-bettercity.

Metropolitan Council. Regional Report: 2010 Performance Evaluation Report to the Minnesota Legislature. St. Paul, MN: Metropolitan Council, 2011.

Miles. "Frequent Flyer Program for Ground Transportation." August 29, 2019. https:// www.getmiles.com/?c=email_sac_rt\&_branch_match_id=623945397987426768.

Miles. "Partners." August 29, 2019. https://www.getmiles.com/partner.

Muller, Peter O. "Transportation and Urban Form: Stages in the Spatial Evolution of the American Metropolis." In The Geography of Urban Transportation, edited by Susan Hanson and Genevieve Giuliano, 59-85. New York, NY: The Guilford Press, 2004.

Nielsen. Get With the Program: Card-Carrying Consumer Perspectives on Retail LoyaltyProgram Participation and Perks. The Nielsen Company, November 2016.

NuRide. "NuRide." July 8, 2019. https://nuride.com/.

O’Neil, Kevin. "Transit Treasure: Ride CTA, buy things, get cash." CTA Tatler. August 29, 
2019. http://www.chicagonow.com/cta-tattler/2011/09/transit-treasure-ride-cta-buythings-get-cash/.

Perk, Victoria, Jennifer Flynn, and Joel Volinski. Transit Ridership, Reliability, and Retention. National Center for Transit Research (NCTR), Washington, D.C.: U.S. Department of Transportation, October 2008.

Rao, Fujie, and Robert J. Summers. "Planning for Retail Resilience: Comparing Edmonton and Portland." Cities, Volume 58, October (2016): 97-106. doi: 10.1016/j.cities.2016.05.002.

Retail Touchpoints. "Relationships, Not Rewards, Are Key to Successful Loyalty Programs." August 29, 2019. https://www.retailtouchpoints.com/features/specialreports/relationships-not-rewards-are-key-to-successful-loyalty-programs.

Roman, Alex. "Transit Agencies Cultivate Customer Base to Grow Rail Ridership." Metro Magazine. August 29, 2019. http://www.metro-magazine.com/rail/article/211462/ transit-agencies-cultivate-customer-base-to-grow-rail-ridership?page=2.

Rowell, David M. "A History of US Airline Deregulation Part 4: 1979-2010: The Effects of Deregulation - Lower Fares, More Travel, Frequent Flier Programs". The Travel Insider. June 21, 2019. https://thetravelinsider.info/airlinemismanagement/ airlinederegulation2.htm.

Sacramento Regional Transit District. "Miles - Get Rewarded for Your Commute \& Travel." August 29, 2019. https://www.sacrt.com/apps/miles-get-rewarded-foryour-commute-travel/.

San Francisco County Transportation Authority, Bay Area Rapid Transit District, and the U.S. Department of Transportation Federal Highway Administration. Lessons from Perks: Evaluation Findings from the BART Perks Test Program. San Francisco, CA: San Francisco County Transportation Authority, June 2018. doi: 10.1177/0361198118792765.

Schlosser, Nicole. "Montreal Transit App Rewards Riders With Personalized Offers." Metro: For Transit \& Motorcoach Business, August 29, 2019. http://www.metromagazine.com/management-operations/article/211834/montreal-transit-apprewards-riders-with-personalized-offers.

Schuetz, Jenny. "Do Rail Transit Stations Encourage Neighbourhood Retail Activity?" Urban Studies, 52(14) (2015): 2699-2723. doi: 10.1177/0042098014549128.

Shaheen, Susan, Adam Cohen, Ismail Zohdy, and Beaudry Kock. Smartphone Applications to Influence Travel Choices: Practices and Policies. Washington, D.C.: U.S. Department of Transportation Federal Highway Administration, Report No. FHWA-HOP-16-023, April 2016. 
Smith, Sandy. "Who Wins With Transit Rider Loyalty Programs." Next City: Inspiring Better Cities: The Works. August 29, 2019. https://nextcity.org/daily/entry/transitrider-loyalty-programs-work.

Southeast Pennsylvania Transportation Authority. "Perks for all!" August 29, 2019. https:// iseptaphilly.com/perks.

Sutter, Charles, Theodore F. Ehrlich, and Richard Stiller. "Impact of Implementation of New York Metropolitan Transportation Authority's MetroCard on Ridership and Revenue of Westchester County Bee-Line Bus System." Paper presented at the Transportation Research Board's 88th Annual Meeting, Washington, D.C.: January 11-15, 2009.

Tavilla, Elisa. Transit Mobile Payments: Driving Consumer Experience and Adoption. Boston, MA: Federal Reserve Bank of Boston, 2015.

Teehan, Sean. "DOT Unveils Transit Rewards Program." Hartford Business, August 29, 2019. https://www.hartfordbusiness.com/article/dot-unveils-transit-rewardsprogram.

Thomas, Richard, 2013. "Urban Mobility Innovation / Nextcity." PowerPoint presentation at the Global Technology Workshop. International Bridge, Tunnel and Turnpike Association, Normandy, France, October 27-29, 2013. https://www.ibtta.org/sites/ default/files/documents/2013/Normandy/Thomas_Richard.pdf.

Tri Delta Transit. "Frequent Use Program Rewards Loyal Bus Riders." August 29, 2019. http://trideltatransit.com/pdf/pr_frequent_rider.pdf.

Tri Delta Transit. "Tri Delta Transit introduces Free Rides with Frequent Rider Rewards." 511 Contra Costa, August 29, 2019. https://511contracosta.org/tri-delta-transitintroduces-free-rides-with-frequent-rider-rewards/?force=desktop.

van Lierop, Dea, and Ahmed El-Geneidy. "Is Having a Positive Image of Public Transit Associated With Travel Satisfaction and Continued Transit Usage? An Exploratory Study of Bus Transit." Public Transport, 10(2), August (2018): 241-256. doi: 10.1007/s12469-018-0175-5.

Visalia Transit. "Participating Retailers." August 29, 2019. https://www.visaliarewards. com/participating-retailers/.

Walker, Jarrett. "Frequent-rider Discounts to Decongest the Peak?" Human Transit, August 29, 2019. https://humantransit.org/2011/06/frequent-rider-discounts.html.

Walker, Rob. "Badges? We Got Badges. We Love Badges! We Want More Badges!: How Foursquare Imported a Visual cue From the Boy Scout Sash to the Web." August 29, 2019. https://slate.com/human-interest/2011/07/foursquare-badges-how-thesocial-networking-service-imported-a-visual-cue-from-the-boy-scout-sash-to-the- 
web.html.

Watkins, Kari, Noreen McDonald, Ruth Steiner, and Billy Williams. Transit in the Era of Shared Mobility. Gainesville, FL: Southeastern Transportation Research, Innovation, Development, and Education Center (STRIDE) at the University of Florida Transportation Institute, January 2019.

Wax, Dustin. “The Science of Motivation.” August 29, 2019. http://www.lifehack.org/ articles/productivity/the-science-of-motivation.html.

Webb, Valerie. Customer Loyalty in the Public Transportation Context. Cambridge, MA: Massachusetts Institute of Technology: Master of Science Thesis in Transportation, February 2010.

Woomer, Eric. "A Rewarding Ride: Visalia Transit Inaugurates Rewards Plan for Bus Riders." August 29, 2019. http://www.valleyair.org/recent_news/News Clippings/2010/In\%20the\%20News\%2008-03-10.pdf. 


\section{ABOUT THE AUTHOR}

\section{CHRISTOPHER E. FERRELL, PH.D.}

Dr. Ferrell began his planning career in 1995 working for the Metropolitan Transportation Commission (MTC) on intelligent transportation system (ITS) applications for traffic management. Since 2000, he has worked as a transportation consultant and most recently as MTl's Senior Research Scientist, focusing on the integration of transportation and land use, and travel behavior. In 2010 he co-founded CFA Consultants, a transportation planning and research firm. Dr. Ferrell completed his doctoral studies in city and regional planning at the University of California, Berkeley in 2005. 


\section{PEER REVIEW}

San José State University, of the California State University system, and the MTI Board of Trustees have agreed upon a peer review process required for all research published by MTI. The purpose of the review process is to ensure that the results presented are based upon a professionally acceptable research protocol.

Research projects begin with the approval of a scope of work by the sponsoring entities, with in-process reviews by the MTI Research Director and the Research Associated Policy Oversight Committee (RAPOC). Review of the draft research product is conducted by the Research Committee of the Board of Trustees and may include invited critiques from other professionals in the subject field. The review is based on the professional propriety of the research methodology. 
Founder, Honorable Norman Mineta (Ex-Officio)

Secretary (ret.),

US Department of Transportation

Chair,

Abbas Mohaddes (TE 202I)

President \& $\mathrm{COO}$

Econolite Group Inc.

Vice Chair,

Will Kempton (TE 2022)

Retired

Executive Director,

Karen Philbrick, PhD

(Ex-Officio)

Mineta Transportation Institute

San José State University

Richard Anderson

(Ex-Officio)

President \& CEO

Amtrak

David Castagnetti (TE 202I)

Co-Founder

Mehlman Castagnetti

Rosen \& Thomas

Maria Cino (TE 202I)

Vice President

America \& U.S. Government

Relations Hewlett-Packard Enterprise

\author{
Grace Crunican* \\ (TE 2022) \\ Retired
}

Donna DeMartino (TE 202 I)

General Manager \& CEO

San Joaquin Regional Transit District

Nuria Fernandez* (TE 2020)

General Manager \& CEO

Santa Clara Valley

Transportation Authority (VTA)

John Flaherty (TE 2020)

Senior Fellow

Silicon Valley American

Leadership Form

Rose Guilbault (TE 2020)

Board Member

Peninsula Corridor

Joint Powers Board

Ian Jefferies (Ex-Officio)

President \& CEO

Association of American Railroads

Diane Woodend Jones

(TE 2022)

Principal \& Chair of Board

Lea + Elliott, Inc.
Therese McMillan

(TE 2022)

Executive Director

Metropolitan Transportation

Commission (MTC)

Bradley Mims (TE 2020)

President \& CEO

Conference of Minority

Transportation Officials (COMTO)

Jeff Morales (TE 2022)

Managing Principal

InfraStrategies, LLC

Dan Moshavi, PhD

(Ex-Officio)

Dean, Lucas College and

Graduate School of Business

San José State University

Takayoshi Oshima (TE 202 I)

Chairman \& CEO

Allied Telesis, Inc.

Toks Omishakin

(Ex-Officio)

Director

California Department of

Transportation (Caltrans)
Paul Skoutelas (Ex-Officio)

President \& CEO

American Public Transportation

Association (APTA)

Dan Smith (TE 2020)

President

Capstone Financial Group, Inc.

Beverley Swaim-Staley (TE 2022)

President

Union Station Redevelopment

Corporation

Jim Thymon (Ex-Officio) Executive Director

American Association of

State Highway and Transportation

Officials (AASHTO)

Larry Willis (Ex-Officio)

President

Transportation Trades

Dept., AFL-CIO

$(\mathrm{TE})=$ Term Expiration

$*=$ Past Chair, Board of Trustees

\section{Directors}

Karen Philbrick, Ph.D.

Executive Director

Hilary Nixon, Ph.D.

Deputy Executive Director

\section{Asha Weinstein Agrawal,}

\section{Ph.D.}

Education Director

National Transportation Finance

Center Director

\section{Brian Michael Jenkins}

National Transportation Security

Center Director

\section{Research Associates Policy Oversight Committee}

Jan Botha, Ph.D.

Civil \& Environmental Engineering

San José State University

Katherine Kao Cushing,

Ph.D.

Enviromental Science

San José State University

Dave Czerwinski, Ph.D. Marketing and Decision Science San José State University
Frances Edwards,

Ph.D.

Political Science

San José State University

Taeho Park, Ph.D.

Organization and Management

San José State University

Christa Bailey

Martin Luther King, Jr. Library

San José State University

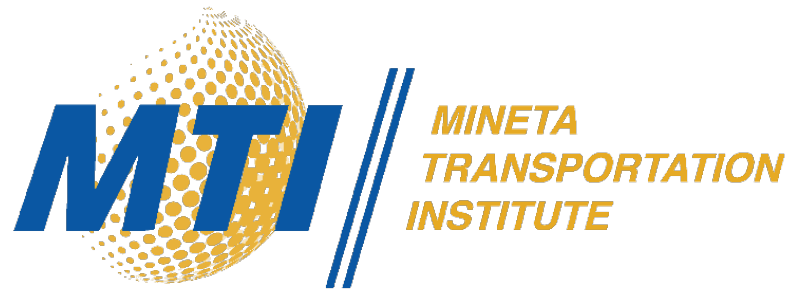

